\title{
Embodying Enlightenment: Physical Culture in Dzogchen as revealed in Tibet's Lukhang Murals
}

\author{
Ian A. Baker
}

\begin{abstract}
The Great Perfection or Dzogchen (rdzogs chen) teachings of Tibet are upheld as revealing the ultimate unconditioned nature of human consciousness without recourse to the transformational rites and practices that characterise the tantric, or Vajrayāna, form of Buddhism from which it arose. While Dzogchen is commonly perceived, and presented, as pertaining principally to the reflexive 'self-liberating' potential of the mind, its practice is traditionally infused by physical exercises that push the body—and thereby consciousness — beyond conventional limits and constraints. Dzogchen's body-oriented approach to the realisation of habitually dormant perceptual and existential capacities is vividly portrayed in a series of late seventeenth-century murals in a once secret meditation chamber in Lhasa conceived during the reign of the Fifth Dalai Lama. The wall paintings illustrate a Dzogchen 'treasure text' (gter ma) revealed two centuries earlier by Terton Orgyen Pema Lingpa (1450-1521) and ascribed to Padmasambhava, the 'Lotus Born' sage credited with having established Dzogchen in Tibet in the eighth century. Embellished with illuminating passages from Pema Lingpa's 'Compendium of Enlightened Spontaneity' (Rdzogs chen kun bzang dgongs 'dus), the Lukhang murals clearly portray the pro-somatic practices (rtsa rlung 'khrul 'khor) held to facilitate realisation of the mind's inherent 'Buddha Nature' (de gshegs snying po, Skt: tathägatagarbha). Illustrated with details of the Lukhang murals, this article presents an overview of Dzogchen's core practices in an attempt to demonstrate that while the 'innate perfection' of Dzogchen can, as tradition upholds, be directly cognised without any modification of mind or body, it is more commonly a consequence of intensive qigong and hathayoga-like practices, fused with Dzogchen's signature 'view' of non-duality (gnyis med). A key chapter of Pema Lingpa's Dzogchen 'treasure text' is appended to the article, further illuminating the fundamental dynamics of mind and body at the heart of the Dzogchen tradition and the ways in which primordial unitary awareness (rig pa) arises vibrantly and unconditionally in response to physiology and perception pushed beyond their accustomed limits, whether in states of waking, sleeping, dreaming, or near-death experiences.
\end{abstract}

\section{Keywords}

Vajrayāna Buddhism, Dzogchen (rdzogs chen), tsalung (rtsa rlung), trulkhor ('khrul 'khor), thogal (thod rgal), treasure texts (gter ma), Pema Lingpa (Padma gling pa) 


\section{The Supreme Yoga}

The 'Great Perfection' (rdzogs chen) teachings of Tibetan Buddhism, also known as Ati, or 'utmost', Yoga' (shin tu rnal 'byor, gdod ma'i rnal 'byor) elucidate the innate 'self-liberating' disposition of human consciousness. Described as both the essence and culmination of the Vajrayāna ${ }^{2}$ Buddhist path to 'pure and total presence' (byang chub kyi sems), Dzogchen frees consciousness from vestigial discontent through sustained and unmediated insight into the non-dual (gnyis med) nature of primordial awareness ( $r i g$ pa). As explicated in the 'Six Vajra Verses' (Rig pa'i khu byug), one of Dzogchen's earliest known literary sources; 'Recognising that everything is self-perfected from the very beginning and beyond the constraints of conceptualising mind, the malady of striving is spontaneously relinquished. One remains immaculately at ease in innate perfection. ${ }^{3}$ Similarly, Padmasambhava, ${ }^{4}$ the eighth-century figure most

${ }^{1}$ Dzogchen, or Ati Yoga (shin tu rnal 'byor), is presented in Nyingma tradition as the culmination of nine processual vehicles for actualising enlightenment, union with all-encompassing awareness transcendent of all afflictive fluctuations of consciousness. The first two vehicles refer to the Hīnayāna stages of Śrāvakayāna and Pratyekayāna that lead to the solitary realisation of the arhat, as represented today by Theravāda Buddhism. The third vehicle, Bodhisattvayana, introduces the Mahāyāna or greater vehicle, and cultivates enlightenment not just for oneself, but for all beings. The fourth, fifth, and sixth vehicles are the so-called Outer Tantras of Kriyātantra, Caryātantra, and Yogatantra, all of which are part of the Vajrayāna, or third turning of the wheel of doctrine, but are still dualistic in their orientation. The three Inner Tantras were transmitted to those deemed of higher capacity and consist of Mahā Yoga, which emphasises the development stage (bskyed rim) of creative perception, Anu Yoga, which cultivates co-emergent bliss and emptiness through completion stage (rdzogs rim) practices based on an imaginal body of channels, winds and essences, and Ati Yoga, the resultant non-duality of Dzogchen with its liberating praxis of primordial, self-existing perfection. The three Inner Tantras of the Nyingma further correlate with the Unsurpassed Yoga Tantras (Anuttarayogatantra) of the Kagyu, Sakya, and Geluk lineages, all of which culminate in the non-dual (Advaitayoga) view of reality as expressed in Essence Mahāmudra (ngo bo'i phyag rgya chen po) which is identical, in outlook, to Dzogchen, the 'Great Perfection', but differs in method and presentation.

2 Founded by Indian mahäsiddha, or realised adepts, Vajrayāna, is a multifaceted and complex system of Buddhist thought and practice which evolved over many centuries. Also known as Tantric Buddhism, Tantrayāna, Mantrayāna, Secret Mantra, Esoteric Buddhism and the Diamond Way or Thunderbolt Way, Vajrayāna, refers to one of three Buddhist vehicles or routes to enlightenment, the other two being Theravāda and Mahāyāna. For discussion of the phases of introduction of Vajrayāna Buddhism to Tibet, see Kapstein 2000; Snellgrove 1987.

${ }^{3}$ Also known as 'The Cuckoo's Song of Total Presence', this seminal text is considered the basis of Dzogchen practices emphasising the nature of consciousness (sems sde). A version of this text was discovered among materials sealed into a chamber at the oasis of Dunhuang in the tenth century, but the text is held by tradition to date originally to the eighth century when Tibet's first Dzogchen master, Vairocana, allegedly received it from Śrī Simha in the legendary land of Uḍ̣ịāna.

${ }^{4}$ Padmasambhava, the 'Lotus Born', is a quasi-supernatural personality in Tibetan Buddhist hagiography who is credited with eight archetypal manifestations and innumerable emanations. 
commonly identified as having established the Dzogchen teachings in Tibet, is said to have proclaimed that 'In its true state the mind is naked, immaculate, clear, without duality, transparent, empty, timeless, uncreated, unimpeded; not realisable as a separate entity, but as the unity of all things.... To know whether or not this is true, look into the nature of your own mind. ${ }^{5}$

Although, as a lived experience, Dzogchen requires no modification of psychophysiological processes — only vivid insight into their essence-it nonetheless relies, in practice, on yogic exercises that push the body, and thereby consciousness, to their physical and psychological limits. These range from physically demanding 'preliminary practices' (sngon 'gro) to supportive qigong and hathayoga-related exercises (rtsa rlung 'khrul 'khor) ${ }^{6}$ that balance and amplify somatic processes prior to undertaking Dzogchen's more widely known and transmitted contemplative techniques of 'cutting through' (khregs chod) and 'leaping over' (thod rgal), the latter involving precise body postures, breathing techniques, and methods of gazing. Auxiliary Dzogchen practices involve condensed renditions of the so-called Six Yogas, ${ }^{7}$ geared towards recognising the

He is said to have originated in Uḍdiyāna, a region known for its syncretic traditions currently encompassing parts of northern Pakistan, Afghanistan, and Kashmir. When asked who he was, he allegedly replied; 'My father is wisdom. My mother is selflessness. My country is Reality, just as it is. I take thoughts as food and have come here to destroy sorrow.' There are clear parallels between the Dzogchen tradition attributed to Padmasambhava and non-dual Kashmiri Śaivism that includes the practice of 'Sambhava Yoga', referring to the radiance of intrinsic consciousness when freed from all ideation. Similarly, Uḍdiyāna, from where Padmasambhava is said to have originated, refers to a specific hațayoga practice, uddiyāna, or 'flying upward', mudrā, used for directing energy and awareness into the body's central meridian ( $r t s a d b u$ ma). For evidence of the influence of Kashmiri Śaivism on the development of Vajrayāna Buddhism, see Alexis Sanderson's extensive publications in the field (www.alexissanderson.com). To compare relevant passages of the śaiva āgama with Dzogchen pith instructions (man ngag), see Singh 1979; Odier 2005.

5 Evans-Wentz (ed.) 1954, p. 183.

${ }^{6}$ rtsa rlung breathing practices that alter the flow of somatic energy are typically enhanced by the dynamic yogic movements of 'khrul 'khor to both improve health and expand the body's capacity for inner experience. Geoffrey Samuel has pointed out that the Tibetan Buddhist Resource Center (TBRC) catalogue alone includes 260 'khrul 'khor-related texts, although little research has been devoted to the subject. He further notes that some of these texts are included in the Tengyur and thus held to be translations of original Indian texts.

7 Associated with the eleventh-century Indian mahāsiddha Nāropā (956-1041), the 'Six Yogas' (na ro chos drug) derive from the 'Yogini Tantras' of Anuttarayogatantra and refer in reality to a larger and shifting set of processual yogic practices directed towards awakening habitually dormant human capacities during the recurring phases of waking, dreaming, and sleeping as well as at the time of death and its aftermath. The inclusion of the Six Yogas in 'rediscovered' Dzogchen treasure texts (gter $m a$ ) suggests the influence on the Nyingma tradition of teachings brought from India to Tibet by Marpa Lotsawa in the eleventh century and propagated within the Kagyu lineage of 'whispered secrets'. For an overview of the Six Yogas and their diffusion in 
Natural State (gnas lugs) at all stages of waking, dreaming, sleeping, and posited post-mortem states of consciousness. In all aspects of Dzogchen practice, the body is cultivated and its natural processes enhanced and ultimately transcended, in order to facilitate effortless abiding in the self-liberated radiance of intrinsic awareness, equated in Dzogchen to the 'Buddha Nature' (bde bar gshegs pa'i snying po, Skt: sugatagarbha) held to be latent within all beings. As stated in the Secret Nucleus, 'The Perfect Buddha is not found in any of the ten directions or four times. Other than the perfect Buddha which is mind-assuch, do not seek the Buddha elsewhere. ${ }^{8}$ As Dzogchen treatises repeatedly point out, the human body is an essential vehicle for the realisation of the radiant and selfless expanse of enlightened awareness obscured by habitual subject-object mentation. ${ }^{9}$

Dzogchen teachings in Tibet were traditionally closely guarded as their uncompromising Zen-like elucidations of the nature of mind were often in conflict with monastic traditions based on scriptural recitation and ceremonial magic. Dzogchen methods for awakening to the posited innate mind of enlightenment were transmitted primarily through Tibet's Nyingma, or 'Ancient' order which traces its origins to the eighth-century Buddhist masters Padmasambhava and Vairocana who are credited with having brought the teachings of Ati Yoga from Uḍdiyāna, a legendary realm at the north-west frontiers of the Indian sub-continent. The Dzogchen lineage is held to have spread beyond Uḍdiyāna with the 'Three Incisive Precepts' (Tshig gsum gnad brdegs) transmitted by the semi-historical Prahevajra (Tib: Dga' rab rdo rje) to his Brahman disciple, Mañjuśrimitra ('Jam dpal bshes gnyen). ${ }^{10}$ Dzogchen evolved in Tibet and neighbouring Himalayan countries from the eighth century onward and, beginning in the eleventh century, through a tradition of

Tibet in connection with the development of the Kagyu, Sakya, and Geluk orders, see Mullin 2006; Dudjom Rinpoche 1991, pp. 284-9; Kongtrol 2005, pp. 330-7.

${ }^{8}$ Guhyagarbha Tantra, Tib: Rgyud gsang ba'i snying po. This Tantra predates the appearance in Tibet of specifically Dzogchen works and is upheld in Nyingma tradition as authenticating Dzogchen's deconstructionist presentation of experiential reality.

9 The 'Reverberation of Sound' (Sgra thal 'gyur), the root tantra for the Seventeen Dzogchen Tantras of the secret instruction series, states that 'the union of body and mind connects primordial space with pristine awareness ... realising that, all beings are naturally buddhas!'

${ }_{10}$ Prahevajra's final testament summarises Dzogchen's existential view, meditative practice, and ubiquitous application. These are encapsulated in outer, inner, and secret precepts: recognising the nature of mind (sems sde), remaining in non-dual 'spaciousness' (klong sde), and applying that realisation in all circumstances (man ngag). These three aspects of Dzogchen are further associated with the interrelated experiences of clarity, open presence, and the unity of emptiness and appearance. 
revealed 'treasure texts' $(\text { gter } m a)^{11}$ discovered by lineal successors of Padmasambhava. While faithful to Dzogchen's original ethos of the primordial purity $(\mathrm{ka} \mathrm{dag})$ of selfless unitary consciousness and non-reliance on external rites, the Dzogchen treasure texts nonetheless increasingly incorporated hathayoga-like techniques that were perceived as supportive and complementary to Dzogchen's core contemplative practices by which the physical body could ultimately be dematerialised into an immortal body of rainbow light ('ja'lus). ${ }^{12}$

${ }^{11}$ Revealed treasure texts ( gter $m a$ ) are invariably attributed to Padmasambhava and typically consist of meditative instructions (khrid), empowerments (dbang), and root tantras (rgyud), with miscellaneous ritual treatises often appended at the end. They can vary in length from a single text to more than one hundred. Treasure texts reinforce tradition by attributing literary and conceptual innovation to the founding figure of Padmasambhava while including new and sophisticated techniques of yogic practice that entered Tibet from the late tenth century onward in a subsequent wave of transmission from Indian mahäsiddhas, or realised adepts. Devotees of Tibet's original Nyingma order maintain that comparable teachings had been transmitted centuries earlier by Padmasambhava to his primary Tibetan consort, Yeshe Tsogyal, who encoded them on 'yellow scrolls' (shog gser) and hid them in rock walls, temple pillars, and other locations to be discovered in future generations by designated 'treasure finders' or terton (gter ston). This practice allowed renewal of Nyingma doctrine to occur within the stability of orthodox tradition. But, as was the case throughout Tibet's history, the ambiguity of the texts' historical sources raised concerns of authenticity while the overtly creative and non-conventional lives of the tertons themselves allowed for the possibility, at least to their detractors, of their subverting the practice to support elaborate agendas of self-advancement. The lack of any traceable Indic source for the revealed treasure texts attributed to Padmasambhava continues to vex Tibetan Buddhist tradition. While certain schools of Tibetan Buddhism view texts such as Pema Lingpa's 'Compendium of Enlightened Spontaneity' (Rdzogs chen kun bzang dgongs' dus) as indisputable expressions of Padmasambhava's enlightened mind and, by extension, the essence of the transcendental Buddha Amitābha that Padmasambhava is held to embody, other schools view the texts with suspicion and at times with outright hostility. Matthew Kapstein describes this historical rift between the idealism of living revelation and a more critical historical orientation as having led, over time, to 'purely political considerations whose perverse alchemy transformed the gold of religious vision into the base metal of violent sectarianism' (Kapstein 2000, p. 135). As Kapstein points out, the great Tibetan scholar and tantric master Tāranātha (1575-1634) had articulated the possibility of a middle ground 'by affirming that while at least some of the treasures were genuinely based upon early materials, they were at the same time, nevertheless, elaborated by their "discoverers". In this formulation alone do we find the possibility of an alternative to the aporia of unimpeachable authenticity versus willful fraud.' (Kapstein 2000, p. 135). See also Kapstein 1989, pp. 217-44 and Gyatso 1993, pp. 97-210. For further discussion of the terma (gter ma) tradition, see Gyatso 1998, as well as Thondup 1986.

12 Tibet's pre-Buddhist Bon tradition also includes hathayoga-like practices but, rather than ascribing them an Indic source, maintains that they originated in Tibet through the lineage of the Shang Shung Nyengyud. They serve a similar role in Bon as supports through which the mind's essential nature can be more readily perceived. For the Bon presentation of Dzogchen, see Namdak and Myrdhin Reynolds 2006; Namdak and Dixey 2002. 


\section{The Lukhang Murals}

In the fifteenth century, the Nyingma treasure master terton Orgyen Pema Lingpa (Orgyan Padma gling pa) (1450-1521), henceforth Pema Lingpa, revealed a highly influential Dzogchen treasure text entitled 'Compendium of Enlightened Spontaneity' (Rdzogs chen kun bzang dgongs 'dus) ${ }^{13}$ from a stūpa above Samye Monastery in Central Tibet. Ascribed to Padmasambhava, the treasure text emphasises Dzogchen pith instructions (man ngag) for realising the exalted state of 'Great Perfection' through body-oriented techniques ranging from methods of hatha and kundalini yoga ${ }^{14}$ to specific postures associated

\footnotetext{
13 'Great Perfection: Compendium of Enlightened Spontaneity' (Rdzogs chen kun bzang dgongs 'dus) is one of three texts revealed by Pema Lingpa that elucidates the Great Perfection (rdzogs chen). Alternative translations of Rdzogs chen kun bzang dgongs 'dus include Sarah Harding's 'Great Completion: Union of Samantabhadra's Intentions'. Kun bzang is a contraction of Kun tu bzang po meaning 'All Good' or 'Ever Good', a name referring to the primordial Buddha and the principle of enlightenment. dgongs pa has been commonly translated as 'intention', but Buddha activity is spontaneous and unpremeditated. dgongs pa can also be translated as 'wisdom', but to retain the spontaneity expressed in Pema Lingpa's presentation of the Dzogchen teachings, I have chosen to render his revealed text as 'Great Perfection: Compendium of Enlightened Spontaneity'. For a full inventory of Pema Lingpa's revealed treasures, see Harding 2003, pp. 142-4. A set of Pema Lingpa's original manuscripts are preserved at Gangteng Monastery in Bhutan. Reproductions were sponsored by Her Majesty the Royal Grandmother of Bhutan, edited by the great Nyingma master Dudjom Rinpoche, and published in 21 volumes by the National Library of Bhutan in Thimphu. Pema Lingpa's treasure corpus is also available as digital scans at Tibetan Buddhist Resource Center (www.tbrc.org) through the efforts of Gene Smith and the generous support of Chris Tomlinson. For more on the life and activities of Pema Lingpa, see Harding 2003; Aris 1988; Tshewang et al. 1995.

${ }_{14} H a t h a$, literally 'forceful', yoga was expounded in a fifteenth-century Sanskrit treatise by Svāmi Svātmārāma entitled Hațha Yoga Pradīpikā. Widely available in modern English translations, the text is one of the oldest surviving works on hathayoga and is dedicated to Siri $\bar{a} d i$ nāth $\bar{a}$, in reference to the Hindu god Shiva. Like the two other well-known classics of hathayoga, Gheranda Sambitā and Siva Sambitä, the manual offers detailed information on yogic postures (äsana) and breathing techniques (prānāyajm) as well as the metaphysical anatomy of channels (nädi) and cakra and psychophysical energy of kundalinī, or candälì (Tib: gtum mo) that underlie both Hindu and Buddhist Tantra. See Samuel 2008; Birch 2011; Singleton and Mallinson, forthcoming, for the development of hathayoga in India. Physical yogic practices in Tibet are generally held to have begun in the eleventh century during the second diffusion of Vajrayana, in particular in association with the Kagyu order's transmission of 'whispered precepts'. The inclusion of hathayoga-like practices in a text ascribed to Padmasambhava supports the contention that the Nyingma tradition of revealed treasures was, at least in part, a way of including in the Nyingma canon advanced tantric methods of internal transformation such as those described in the Six Yogas of Nāropā as well as the similarly formulated Six Yogas of Niguma that date from the same period and continue to be passed down within the Shangpa Kagyu sub-order. Like the Hatha Yoga Pradīpikā, Pema Lingpa's 'treasure text' makes clear its intent to illuminate the essence of tantric methods that, within monastic settings, were often burdened with liturgical rites and coded language that concealed more than they revealed.
} 


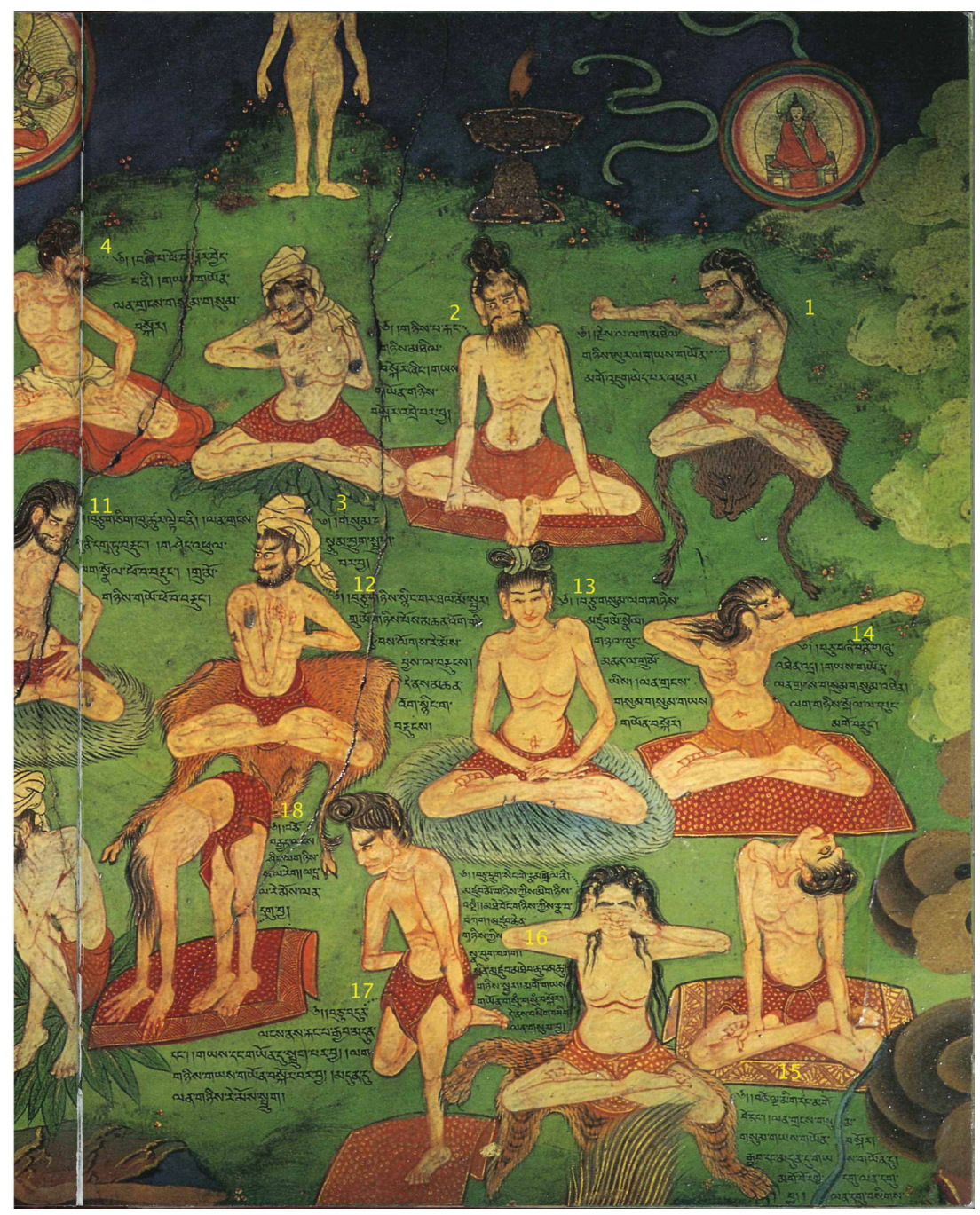

The Lukhang Murals 1 


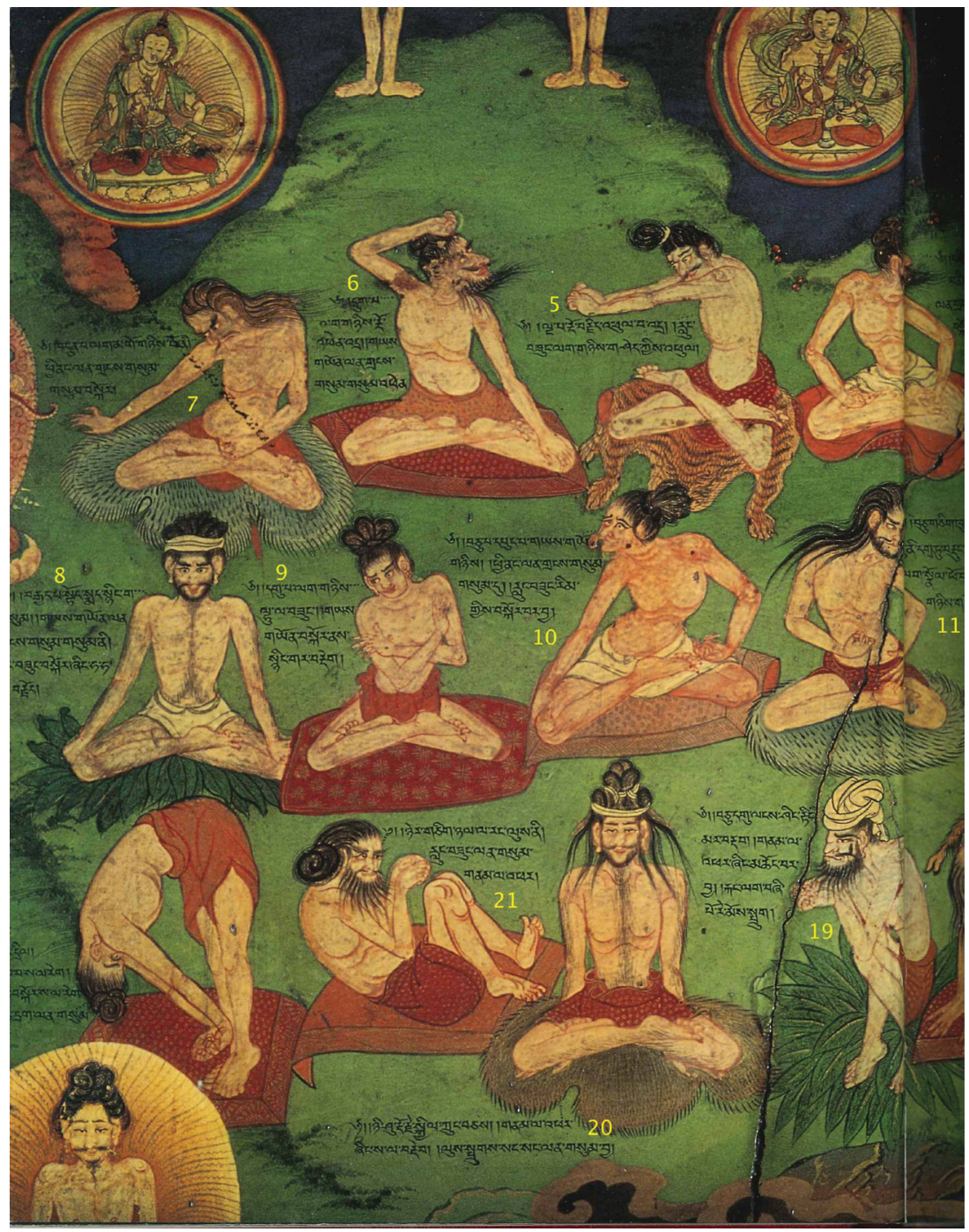

The Lukhang Murals 2 


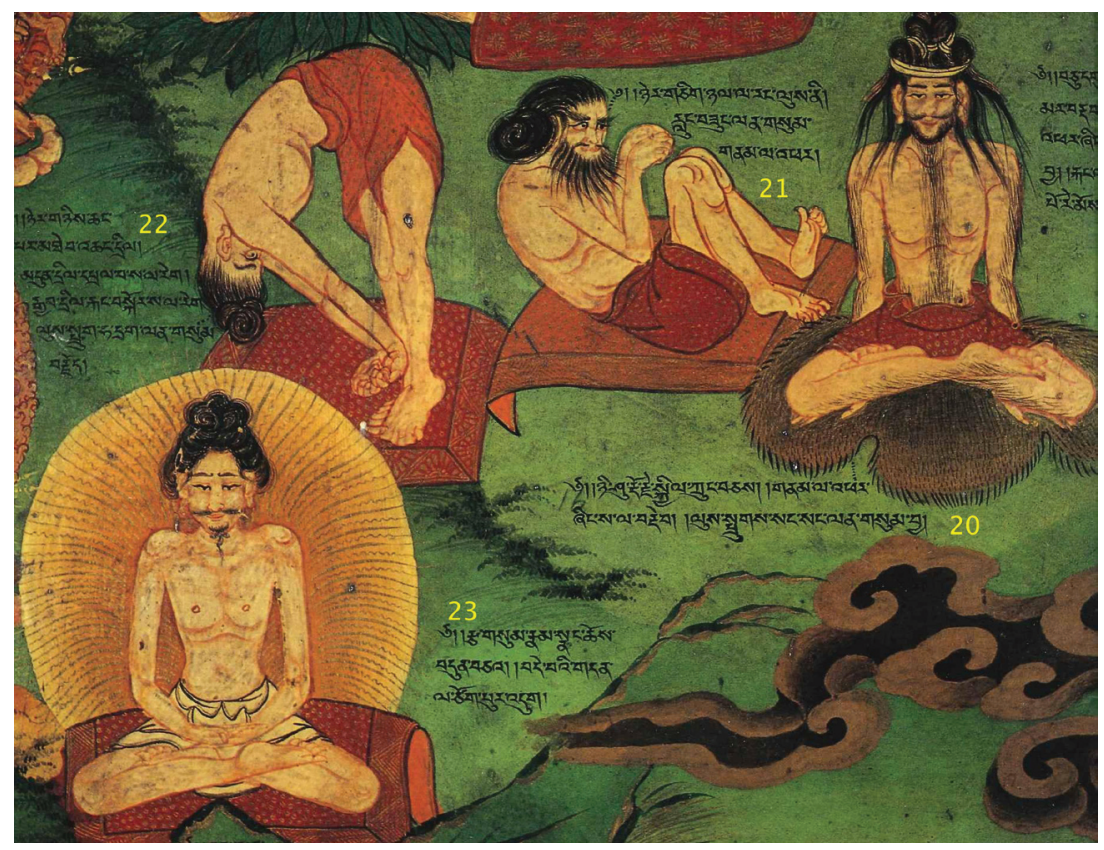

The Lukhang Murals 3

with Dzogchen's ultimate goal of transforming the psychophysical constituents of the body into boundless light. The treasure text has had an enduring influence throughout the Himalayan world and elucidates the role of physical cultivation in teachings dedicated to attaining what Vajrayāna Buddhist tradition upholds as humankind's highest potential.

In the late seventeenth century, at the height of Tibet's political consolidation and cultural efflorescence, ${ }^{15}$ the reincarnation of the Fifth Dalai Lama (Ngag dbang blo bzang rgya mtsho) (1617-82) was identified as Tsangyang Gyatso (Tshang dbyangs rgya mtsho), a direct descendent of the Bhutanese Treasure Revealer Pema Lingpa, discoverer of the 'Compendium of Enlightened Spontaneity'. ${ }^{16}$ Tibet's acting ruler at the time, Desi Sangye Gyamtso (Sde srid sangs rgyas rgya mtsho) (1653-1705), was furthermore a lineage-holder of

15 For details of events at this time, see Aris 1988; Baker 2011.

16 The Sixth Dalai Lama was a direct descendent of Pema Lingpa through his father, the Nyingma master Rigdzin Tashi Tendzin (Rig 'dzin Bkra shis bstan 'dzin) (1651-97), who hailed from the mountainous regions east of Bhutan and disseminated Pema Lingpa's lineage of noncelibate lay ordination to others of his Nyo clan, the progenitors of Bhutan's nobility and eventual royal family. 
the practices described in Pema Lingpa's treasure text, leading him to oversee the creation of a set of murals illustrating the contents of Pema Lingpa's revealed treatise on the walls of a meditation chamber reserved exclusively for the Dalai Lamas and their closest preceptors and attendants. ${ }^{17}$ Representing Tibet's highest spiritual insights, beyond monastic convention, the murals serve as instructional guides to the physical practices that infuse the Dzogchen tradition and the degree to which the body was perceived and cultivated as a potent medium of spiritual development. ${ }^{18}$

The hidden murals lie on the uppermost floor of the Lukhang (klu khang), or Temple to the Serpent Spirits, situated on a willow-fringed lake beneath the southern escarpment of the Dalai Lama's Potala Palace in Lhasa. ${ }^{19}$ Flowing across the walls within a surreal blue-green landscape influenced by the painting styles of Qing dynasty China, the murals cover three sides of the chamber and illustrate the principal contents of Pema Lingpa's treasure text, 'Compendium of Enlightened Spontaneity'. ${ }^{20}$ Apart from Padmasambhava's

17 As Pema Lingpa's teachings spread within Tibet, 'Compendium of Enlightened Spontaneity' became central to the curriculum at Orgyen Mindroling, a prominent Nyingma monastery founded between 1670 and 1676 by Minling Terchen Gyurme Dorje (Smin gling gter chen gyur med rdo rje) (1646-1714), known also as Rigdzin Terdak Lingpa (Rig 'dzin gter bdag gling pa). Towards the end of the 17th century, Terdak Lingpa wrote an extensive commentary to Pema Lingpa's 'Compendium of Enlightened Spontaneity' entitled 'Total Illumination of the Essence: The Teaching Manual for The Union of Samantabhadra's Intentions' which continues to be used today at teaching centres associated with H. E. Gangteng Tulku Rinpoche, one of Pema Lingpa's three contemporary incarnations. Summarising the contents of the Lukhang murals, the commentary begins with teachings on sngon 'gro (the common preliminary practices of Refuge, Bodhicitta, Vajrasattva, Mandala Offering, and Guru Yoga) followed by the Dzogchen extraordinary preliminaries (Inner, Outer, Secret, and Ultra Secret 'khor 'das ru shan, 'distinguishing samsära and nirväna'). The text then directly introduces intrinsic awareness (rigpa) and the associated practices of $k a$ dag khreg chod, thod rgal, the four visions, arriving at direct experience, and transferring consciousness at the moment of death. Terdak Lingpa transmitted these teachings to Ngawang Lobsang Gyatso (Ngag dbang blo bzang rgya mtsho), the Fifth Dalai Lama (1617-82) as well as to Tsangyang Gyatso, the Sixth Dalai Lama (1683-1706), who, after his enthronement in 1697, rejected monastic ordination in favour of esoteric yogic practices such as those disclosed in Pema Lingpa's treasure text.

${ }_{18}$ The link between Pema Lingpa's treasure text and the Lukhang murals was identified in 2002 by Jakob Winkler. See Winkler 2002, pp. 321-43.

${ }^{19}$ For details concerning the contents of the murals on the two lower floors of the Lukhang, see Luczantis 2011.

${ }^{20}$ According to the current Fourteenth Dalai Lama, the paintings that inscribe the private meditation chapel were executed under the combined direction of Desi Sangye Gyamtso and Terdak Lingpa's younger brother, the accomplished artist Minling Lochen Dharma Shri (16541717). Prior to Desi Sangye Gyamtso's production of the Lukhang murals, he masterminded the creation of a series of 79 scroll paintings depicting the Tibetan medical system as it was taught at Lhasa's Chakpori Medical College, which he founded in 1696. The artistic and didactic paintings were based on the Blue Beryl (Vaidürya sngon po), the Desi's extensive commentary on the 
25 Tibetan disciples who are shown grouped around the eighth century Tibetan emperor Trisong Deutsen (Khri srong lde'u btsan) and images of Pema Lingpa, his previous incarnation Longchen Rabjampa (1308-64), and his descendant, Rigdzin Tashi Tendzin - father of the Sixth Dalai Lama-all other figures in the murals are of Indian origin. These include an entire wall dedicated to the Indian mahasiddha (grub thob chen po) progenitors of Tibet's tantric lineages as well as the yogic practitioners portrayed on the north and west walls who are identified by an accompanying inscription as rși, the Vedic seers of ancient India. The Lukhang murals and Pema Lingpa's treasure text thus promote an ideological Indian genesis for the Dzogchen teachings, in defence against rival claims that fault Dzogchen for its lack of verifiable Sanskrit sources. ${ }^{21}$

\section{Preludes to Perfection}

Advanced practice in Vajrayāna, or Tantric Buddhism, is customarily preceded by foundational practices called Ngondro (sngon 'gro), designed to transform the adept's subjective experience of reality. These generally consist of development phase (bskyed rim ${ }^{22}$ methods of visualisation and mantra recitation that reorient consciousness and develop concentration and insight. These are customarily followed by completion stage (rdzogs rim) practices based on a metaphysical anatomy of channels, winds, and subtle essences. These methods lead, in turn, to the enlightening realisation of the inseparability of outer and inner experience. Dzogchen differs from tantra in maintaining that enlightenment is spontaneously present as our innermost nature and needs only to be recognised. The foundational practices in Dzogchen thus forgo graduated liturgies and elaborate rites of transformation and focus

foundational Four Medical Tantras (Rgyud bzhi) that had been compiled in the twelfth century and which continue to form the basis of Tibetan medical practice today. The medical paintings generated by the Desi, in collaboration with Tibet's top artists and physicians, continue to be reproduced throughout the world, although less now for instructional purposes than for their artistic merit and the insight they provide into Tibetan civilisation at its height of artistic and cultural production. See Gyatso 2012 for an overview of the various copies that have been produced of the 79 medical thangkas. Also see Parfionovitch, Dorje and Meyer 1992 and Baker and Laird 2011, which presents a late twentieth-century Nepalese rendition.

${ }^{21}$ The presence of the rssi also establish a clear case against rival Bonpo claims that Dzogchen originated in the pre-Buddhist civilisation of Zhang Zhung in Western Tibet. For the Bon presentation of Dzogchen, see Namdak and Myrdhin Reynolds 2006; Namdak and Dixey 2002.

${ }^{22}$ For a concise presentation of the development stage (bskyed rim) of Mahā Yoga associated with sngon 'gro, see Dudjom Rinpoche 1991, pp. 275-83. See also chapter 18 in Kongtrul 2005. 
instead on embodying primordial awareness $(r i g p a)$ in every conceivable circumstance.

Divided into Outer, Inner, Secret, and Ultimately Secret methods for distinguishing the enlightened state of Nirvanna from the self-deceptions of Samsära, Dzogchen's foundational practices are called Korde Rushen ('khor 'das ru shan) and are normally undertaken in wilderness settings. Although their purpose is to induce a radical reorientation of consciousnessdistinguishing the contents of conscious from consciousness itself-the methods by which this is achieved involve pushing both body and mind beyond all habitual limits. In the practices of Outer Rushen, the adept is instructed to physically act out conjured existences from heavens to hells and thus to recognise the self-created nature of conditioned existence. These practices are illuminated on the western wall of the Lukhang murals in images such as that of a yogin shown leaping like a rogue elephant through a shape-shifting landscape of blues and greens. As a Dzogchen treatise entitled 'Flight of the Garuda', contemporary with the Lukhang murals, instructs:

With the conviction that Samsāara and Nirvāna are of one taste... walk, sit, run and jump, talk and laugh, cry and sing. Alternately subdued and agitated, act like a madman. Finally abide in a state of ease and contentment.... Practising in this way your realisation becomes as vast as the sky and your meditation naturally radiant... Without reference points, prejudice or attachment, your actions become spontaneous and saintly, making no distinction between self and others. Detached from your utterances, your speech is like a melodious echo. Without desire for anything at all you are like a celestial eagle soaring through space, or like a fearless and intrepid lion... free from the very beginning, like bright clouds in the sky. ${ }^{23}$

When body and mind have exhausted their capacity for consciously directed dramatic expression, one rests in a state of lucid relaxation ( rnal du ba), corresponding to the savāsana, or 'corpse' pose, of hathayoga.

By alternating unrestrained enactment of the imaginative projections of the mind with pristine objectless awareness, the practitioner of Outer Rushen discovers how Samısāra, the state of dualistic distraction, and Nirvāna, open selfless presence, emerge from the same 'primal purity' ( $k a$ dag) beyond being and non-being. As Padmasambhava explicates in a treasure text entitled 'Liberation Through Seeing with Naked Awareness' (Rig pa ngo sprod gcer mthong rang grol): 'Samsāra and Nirvāna have no difference other than being unaware or aware [of intrinsic reality].... Since we are not deluded by perception but by fixation, Liberation naturally occurs when we recognise that fixated

${ }^{23}$ See Dowman 1984. For a detailed account of the relation of Pema Lingpa's texts to the different sections of the Lukhang wall paintings, see Winkler 2002, pp. 321-43. 
thoughts are only mind grasping at its own empty manifestations.' Through the cathartic improvisations ${ }^{24}$ and physical actions of Outer Rushen, the practitioner releases all inhibitions and attachments and realises a freer dimension of being, based on the mind's essential and abiding nature rather than its transient expressions.

The practices of Inner Rushen ${ }^{25}$ focus attention on six areas along the central axis of the physical body and soles of the feet correlated with inhibiting psychological potentialities and karmic traces. Envisioning associated 'seedsyllables' (bija mantra ${ }^{26}$ at each of the six points, one clears them of all subconscious residue with the intonation and visualisation of blazing white, red, and blue light resounding from the seed mantras Om, Ah, and Hum, representing the triune totality of pristine awareness. Consciousness thus shifts from identification with the body's materiality to its underlying luminescence (nang gsal). ${ }^{27}$ As with the practice of Outer Rushen, sessions focused on the physical body are alternated with motionless periods of concept-free awareness in which thoughts dissolve within the encompassing space of primordial awareness (rig pa).

Inner Rushen's clearing of subconscious somatic obscurations prepares the body for the practices of Secret Rushen which commence with adopting a highly strenuous isometric posture- the 'position of the vajra' — which, supported by associated mental imagery, pushes body and mind into a state of positive eustress leading to the emergence of adaptive mental and physical capacities. Standing tensed with heels together, knees stretched out to the

${ }^{24}$ The methods of Outer Rushen recall the creative and empowering dramatisations of psychic contents used in therapeutic modalities such as Psychodrama, defined by its founder Dr J. L. Monroe as 'the science which explores the truth by dramatic methods.' Monroe was the author of an influential book, The Theatre of Spontaneity (1924), which addresses the cathartic effects of uninhibited self-expression in therapy and personal growth.

${ }^{25}$ The precise instructions for Korde Rushen practices vary between different Dzogchen lineages. In some, the 'Purification of the Six Lokas' as described here is performed prior to the Outer Rushen described above. As with all aspects of Dzogchen, the key point is never technique but the end result: integrating awareness of the mind's innermost non-dual nature within all circumstances and experience.

${ }_{26}$ The syllables Ah, Su, Nri, Tri, Pre, and Du correlate with the forehead, throat, heart, navel, base of the trunk, and soles of the feet. The upper five centres are also associated with seedsyllables representing the Five Elements. Early reference to practices associated with the recitation of the panca bhüta (five element) bija mantras (Ham, Yam, Ram, Vam, and Lam) can be found in the Shri Jabala Darsana Upanishad, composed between 200 BC and 200 AD.

${ }^{27}$ Photon emission associated with bioluminescence within humans and other species has been identified as a side-effect of metabolic reactions, the result of highly reactive free radicals produced through cell respiration interacting with free-floating lipids and proteins. The 'excited' molecules that result can react with chemicals called fluorophores to emit photons (The Guardian, 17 July 2009). 
sides, chin to larynx, and the hands palm to palm above the crown of the head while visualising oneself as an indestructible blazing blue vajra ( $r$ do rje), the practitioner observes the flow of energy and sensation within the body while pushing through barriers of pain and exhaustion. The position is held until the body physically collapses and then is continued on the ground to whatever degree is possible. Then, with the resounding of the seed-syllable Phat, one lies down in a state of unconditioned concept-free awareness. When thoughts arise, one repeats the process in continuing cycles of effort and repose. More than any other Dzogchen practice, the 'vajra posture' engages the physical body in ways designed to alter the flow of psychosomatic energies and to embody experientially the mind's capacity to transcend and gain from physiological stress as it identifies ever increasingly with the essence of consciousness, rather than its adventitious forms including the illusory notion of an abiding self. ${ }^{28}$

The body practices of Secret Rushen are followed by practices of sound and vibration in which a blue seed-syllable Hum is intoned and visualised as multiplying until small Hums fill the entire universe. The syllables and sounds of Hum then fill one's entire body propelling it imaginatively through space. At the end of the session one again lies down as in the practice of the body and rests in open presence. When thoughts arise one begins the practice anew, using the primal energy represented by the seed-syllable Hum to alter habitual perceptions and conceptions of reality. According to the texts, signs of accomplishment include physical bliss, mental lucidity, and non-conceptual awareness.

The subsequent mind practice of Secret Rushen uses the seed-syllable and sound of Ah to enter into direct experience of the pure potentiality, or emptiness that underlies all appearances. Dissolving all perceptions into effulgent light, one remains in a unified state of luminous cognition, beyond conceptions of time and space. The quiescent culmination of the mind component of Secret Rushen forms the basis for Ultimately Secret Rushen in which the energetic currents of one's inner being are expressed dynamically 'in order to free what has been stabilised'. Spontaneously manifesting as a wrathful tantric deity representing the creative volatility of sensation, thought, and emotion, one stands with hands formed into horned mudras, pivoting from left to right on heels driven into the earth. With eyes rolling in the sky, one emits loud thought-subduing laughter from the deepest core of one's being, filling all of space with the syllables and sounds of $\mathrm{Ha}$ and $\mathrm{Hi}$. As in all Rushen practices,

${ }^{28}$ The development of increased mental and physical capacities through pushing through habitual limits recalls the biological phenomenon of hormosis whereby beneficial effects such as increased strength and resilience, growth, and longevity can result from deliberate and systematic exposure to therapeutic stress. 
the body is used to its fullest potential to bring the mind to an innate state of lucid, all-pervading awareness, the foundation for all subsequent Dzogchen practices and ultimate freedom within all experience.

\section{Flowing Wholeness}

A seminal chapter of Pema Linga's treasure text 'Compendium of Enlightened Spontaneity' is illustrated on the north wall of the Lukhang temple, further illuminating the role of physical practices in Dzogchen. Entitled 'The Secret Key to the Channels and Winds' (Rtsa rlung gsang ba'i lde mig), ${ }^{29}$ the chapter focuses on methods of self-cultivation that view the body as a vehicle for realising a liberated condition beyond all physical and conceptual limits. Based on the Dzogchen formula of 'Four Sessions for Realising Buddha Nature' (thun bzhi sangs rgyas ro mnyam pa nyid), the interconnected practices are undertaken at dawn, daytime, dusk, and night and reframe the Six Yogas of tantric tradition in the context of Dzogchen's radical view of non-duality. ${ }^{30}$

Unusually for a Dzogchen treasure text, the chapter begins with a description of 23 yogic exercises ('khrul 'khor) that, combined with specific breathing techniques, ${ }^{31}$ are held to clear the pathways of the channels (rtsa) and activate the flow of awareness through the body's central meridian (rtsa dbu ma).

${ }^{29}$ Rdzogs chen kun bzang dgongs 'dus, vol. 2, pp. 33-40. 'Winds and channels' (rtsa rlung. Skt: $n \bar{a} \bar{d} \bar{i} v \bar{a} y u$ ) refer to tantric representations of the body as a flow of subtle energies that, harnessed and controlled through yogic practice, lead to illuminating states of awareness. The principal energy channels represented in the Lukhang murals are the body's central channel (rtsa dbu ma, Skt: avadhüti) and the paralleling 'solar' and 'lunar' side channels (rtsa ro ma and rtsa rkyang ma).

${ }^{30}$ In contrast with Kagyu, Sakya, and Geluk presentations of the Six Yogas, Pema Lingpa's 'Secret Key' emphasises the Dzogchen approach of 'self-liberation' rather than that of transformation (see also note 7).

The order of the 'four sessions' varies between Dzogchen lineages. The Yeshe Lama, for example, describes them as follows: Before sunrise, one focuses on a white Ah emerging in the sky before one from the white Ah at the heart. During the daytime, one meditates on the natural visions of thod rgal. At dusk, one practises gtum mo. During the night, one withdraws the senses into a luminous Ah in the vase of the heart (she bya bum 'jug).

31 The breath or vital energy (rlung, Skt: präna) of the body is often likened to a horse and the mind to the rider of the horse. The movements of 'khrul 'khor, sometimes called Yantra Yoga, are normally performed with the breath held in the lower abdomen 'like a vase' (bum can, Skt: kumbhaka) in order to direct the pränic winds into the body's central meridian and alter the flow of consciousness. When combined with the 'Four Sessions for Realising Buddha Nature', the practices of 'khrul 'khor are normally undertaken before the evening practice of gtum mo or in the early morning before the practice of thod rgal. In thod rgal, however, the practitioner refrains from any manipulation of the prannic winds so as to directly engage primary non-dual consciousness. This is accomplished through an alternative network of 'light channels' ('od rtsa). 
The exercises culminate in the seven-point meditation posture (rnam snang chos $b d u n)^{32}$ that forms the basis for the subsequently described evening practice of 'gnostic fire' (gtum mo) in which the physical senses are drawn inward towards the experience of 'four joys' (dga' ba bzhi, Skt: caturānanda) at specific points along the body's central axis, giving rise to the self-transcending rapture of coemergent bliss and emptiness (bde ba'i stong pa nyid). ${ }^{33}$ The text goes on to describe the process of 'retaining wakefulness in the vase': practices of lucid sleep and dreaming whereby the habitual divisions between conscious and subconscious states are gradually overcome as the inner winds (rlung, Skt: prāna) resolve at the heart-centre into all-pervasive Luminosity ('od gsal)..$^{34}$ Pema Lingpa's text next describes 'reviving natural awareness at dawn', a method involving the propulsion of the heart-syllable Hum through the crown of the head to a bow's length in front and above until it naturally dissolves and becomes co-extensive with infinite space, the ultimate posited nature of mind and body. The text then goes on to introduce the daytime practice of thod rgal, or 'leaping over', by which the mind, through attending to spontaneous displays of numinous photonic spheres (thig le), ${ }^{35}$ becomes coextensive with the expanse of reality (chos kyi dbyings, Skt: dharmadhätu) and the body, at the time of death, dissolves into rainbow light, the subtlest expression of the five elemental energies held to comprise the manifest universe.

32 The seven points consist of the legs in full lotus position, the spine erect, the shoulders broadened, the neck bent slightly forward, the hands in the gesture of equanimity (with the right hand resting on the left palm), the tip of the tongue touching the palate, and the gaze directed beyond the tip of the nose.

33 The bliss that is cultivated through the practice of gtum mo represents the transformation of dualistically-oriented desire into innate rapture beyond subject or object (bde ba chen po, Skt: mahäsukha, sahajānanda). The process is described through the experience of four progressive states of bliss, each associated with a different energy locus along the body's central axis, and culminating in open enstatic awareness beyond divisions of pleasure and pain.

34 The practices of inner yoga described in the chapter 'The Secret Key to the Channels and Winds' are elaborated in other chapters of 'Compendium of Enlightened Spontaneity' such as one entitled 'The Secret Practice of Gnostic Fire (gtum mo)' and another on 'taking desire as the path' entitled 'Churning the Depths of Samsara'. For a detailed description of the practice of gtum mo, see Yeshe 1998.

35 The Tibetan word thig le (Skt: bindu) has multiple meanings depending on context. Within thod rgal practice, thig le refer to spheres of multicoloured light that mutate into an infinite variety of intermediary forms held to represent the inherent dynamics of primordial awareness ( $r i g p a)$. As entoptic phenomena (visual effects whose source is within the eye itself as images cast upon the retina), thig le also bear comparison with muscae volitantes- 'floaters' that can spontaneously arise within the visual field as luminous chains or drifting orbs - as well as with phosphenes, subjective perceptions of light in the absence of light actually entering the eye, such as when one presses on one's eyeballs. 
While all of the meditative practices described in Pema Lingpa's text involve the support of the physical body, the sequence of 23 hathayoga-related movements illustrated on the northern wall of the Lukhang are the most revealing. While analogous exercises are described in the Hevajra Tantra and other early Vajrayāna Buddhist works for facilitating the transformative flow of kundalini (gtum mo, Skt: candālì) through the body's central channel (rtsa dbu ma, Skt: avadhüti), no definitive records exist of the inclusion of such practices in early Dzogchen. Nonetheless, rtsa rlung 'khrul 'khor forms a major part of the Dzogchen gter ma tradition from the eleventh century onwards when practices based on the body's 'inner mandala' (nang pa'i dkyil 'khor) of subtle energy channels were introduced in Tibet through the Kagyu and Sakya lineages. The Nyingma tradition of inspired revelation continues to this day, however, in the appearance of works such as the 'Union of Sun and Moon' ('khrul 'khor nyi zla kha sbyor gyi dgongs 'grel dri med nor bu'i me long) which Tibetan scholar and meditation master Chogyal Namkhai Norbu attributes to Vairocana, a Tibetan contemporary of Padmasambhava who lived during the eighth century. The text's detailed presentation of 108 sequenced movements, linked by precise breathing methods for directing the flow of internal energy, includes postures that are otherwise known only in works of hathayoga that appeared in India from the fifteenth century onward. A verifiable historical source for the text translated and published by Namkhai Norbu as Yantra Yoga: The Tibetan Yoga of Movement ${ }^{36}$ would change not only current understanding of the history of postural yoga, but would also clearly identify the existence of rtsa rlung and 'khrul 'khor practices in Tibet prior to their introduction through the Kagyu and Sakya lineages during the second diffusion of Vajrayāna that began in the eleventh century.

Pema Lingpa's 'Secret Key to the Winds and Channels' includes many of the same movements described in Vairocana's 'Union of Sun and Moon'. It also bears strong similarities to the 'khrul 'khor practices promulgated by Pema Lingpa's preceding incarnation, Longchen Rabjampa (Klong chen rab 'byams pa) (1308-64), as well as those codified in the 'Heart-essence of Infinite

\footnotetext{
${ }^{36}$ According to Namkhai Norbu, Vairocana received the transmission of Yantra Yoga ('khrul 'khor) from Padmasambhava who, in turn, had received it from a Nepalese mahäsiddha named Humkara who had himself learned it from the great adept Shri Simha, an early Dzogchen lineage-holder who had spent considerable time at Mount Wutai in China. The esoteric movements of 'khrul 'khor as practised in Dzogchen resemble not only Indian hathayoga but also Taoist-Chan Buddhist methods of qigong that were current at Mount Wutai within The East Mountain Teachings. Further research may thus indicate syncretic origins for Tibet's rtsa rlung and 'khrul 'khor practices. For elucidation of 'khrul 'khor within Tibet's Bon tradition, see Wangyal 2011; Chaoul-Reich 2006.
} 
Expanse' (Klong chen snying thig), a mind treasure revealed by the scholar and adept Jigme Lingpa (1730-98). As all traditions of Dzogchen maintain, the practice of rtsa rlung and 'khrul 'khor can result in improved health and wellbeing and prepare the body for inner tantric practices such as gtum mo, but their primary function within Dzogchen is to coordinate the body's psychosomatic winds (rlung, Skt: pranna) so that the nature of awareness becomes ever more manifest and embodied through the Dzogchen contemplative techniques of thod rgal, or 'leaping over'.

\section{The Body of Light}

'The Secret Key to the Channels and Winds' presents the 'khrul 'khor exercises as preparations for the contemplative practices of lhun grub thod rgal, or 'leaping into spontaneous presence', ${ }^{37}$ which include prescribed body postures, breathing techniques, and associated gazes (Skt: $d r s t ̦ i$ ) for shifting consciousness from left- to right-brain activity correlated with unitary awareness and the dissolution of distinctions between subject and object. Using the support of sunrays and the sky, awareness expands from restricted egocentric consciousness to a selfless totality and the spontaneous display of what is held to be intrinsic non-dual reality. The physical body is upheld as the vehicle by which awareness eventually expands to encompass all dimensions of being, described in Vajrayāna as the triune 'bodies' (sku gsum, Skt: trikāya) of Dharmakāya, Sambhogakāya, and Nirmānakāya, referring respectively to infinite undifferentiated totality, intermediate visionary experience, and manifest temporal reality.

Specific body postures and gazes are associated with each of the three kāyas, and the practitioner may freely shift between them during a single session of contemplation while maintaining 'three-fold motionlessness of body, eyes, and consciousness'. As further described in Pema Lingpa's treasure text, the Dharmakāya posture of a seated lion involves squatting on the ground with the soles of the feet together and the hands resting on the ground in front in vajra fists (with the tips of the thumbs touching the base of the ring finger). The upper body is extended upwards with the chin tucked slightly in and the spine and back of the neck straightened so as to allow the free flow of vital energies through the cranial arteries and associated 'light channels' connecting the heart and eyes. With the breath extended outward through gently parted teeth and lips, the eyes are rolled upwards past an imagined protuberance at the crown of the head into

37 See Namdak and Dixey 2002; Chagme 2000; Baker 2011, pp. 116-21. 
the limitless expanse of sky. ${ }^{38}$ In the Sambhogakayya posture of a reposing elephant, one lies down with the knees tucked beneath one's chest, toes extended behind, elbows on the ground and hands placed either in front as vajra fists or cradling the chin as the spine elongates and the eyes gaze to the sides into pure visions reflecting the innate activity of consciousness and perception. In the Nirmannakaya posture of the sage (rsii), one squats with one's ankles together, knees pressed against the chest, and one's arms crossed in front either with hands resting in the armpits or hugging the knees. The gaze is directed slightly downward through half-closed eyes to control the body's vital energies and bring the mind to stillness. As Pema Lingpa's text maintains, pristine awareness dwells like a lamp in a vase at the heart of the physical body but only manifests as direct experience by maintaining the key points of posture, 'just as the limbs of a snake only become apparent when it is squeezed'.

The physical postures, suspended breath, and raised, lowered and sidelong gazes used in the Dzogchen practice of thod rgal serve as 'doors' to the direct experience of the multi-dimensionality of being beyond the single dualistic dimension to which human beings are habitually constrained. The indwelling pristine awareness that liberates consciousness is posited as the innermost essence of the heart (snying thig), and all methods of Dzogchen are directed towards making this a lived reality. The innate radiance (lhun gyis grub pa) of the heart-centre is held to manifest first as flickering and darting gossamer strands and later as spontaneously present spheres of light through a subtle channel that, like a white silken thread and 'far-ranging noose' connects the heart and eyes. The thig le, or subtle essences, appear in the empty mirror of the sky as reflections of innate reality and develop through four sequential visions. ${ }^{39}$ The halos of light ultimately divide and transform into five concentric circles, the central one symbolising pure unmanifest potentiality. As the circle widens through steady gaze, it eventually pervades immeasurable space as all difference between subject and object, mind and body, vanishes in the boundlessness of enlightenment. ${ }^{40}$

\footnotetext{
38 This gaze correlates with śämbhavimudrā in hathayoga, which is said to synchronise the two hemispheres of the brain and lead directly to samädhi. See Birch 2011.

39 The 'Four Visions' of thod rgal are described as the Direct Perception of the Ultimate Nature, the Vision of Increasing Experience, the Perfection of Intrinsic Awareness, and the Dissolution of [phenomena into] the Ultimate Nature. The visions are said to arise from the heart as reflections of the body's purified channels, energies and subtle essences. For further details, see Baker 2011.

${ }^{40}$ This process echoes Matthew 6:22: 'Therefore when thy eye be single, thy whole body will be full of light'.
} 


\section{Conclusion}

The Lukhang murals illustrating Terton Orgyen Pema Lingpa's treasure text 'Compendium of Enlightened Spontaneity' vividly reveal the essential role of the physical body in cultivating the integral states of awareness associated with Dzogchen, or Ati Yoga. From foundational practices that push body and mind to unaccustomed and instructive extremes to hathayoga exercises for awakening the body's 'inner mandala' (nang pa'i dkyil 'khor) of subtle channels and vital energies to the prescribed body postures for experiencing the visionary display of the body-mind's innermost essence (snying thig), Dzogchen is permeated by pro-somatic practices that lead to integrated, self-transcending dimensions of being, held to represent the highest capacities of mind and body. Pema Lingpa's 'Secret Key', as illuminated in the Lukhang murals, offers valuable insight into formerly hidden yogic practices within Tibetan Buddhist tradition as well as opportunity for further reflection on the relationship between mind and body and the diverse ways that the human condition can be optimised both through systematic cultivation and spontaneous reorientations of consciousness. As Pema Lingpa's revealed treasure text proclaims; 'Through the unmediated perception of reality, conceptual analysis naturally subsides.... Free of conflicting views, all things arise as intrinsic Luminosity.... As tainted aggregates dissolve, the body itself is naturally enlightened!' 41

${ }^{41}$ Rdzogs chen kun bzang dgongs 'dus, (TBRC Archives), unpublished translation by David Christiansen and Ian Baker. 


\section{APPENDIX}

'THE SECRET KEY TO THE CHANNELS AND WINDS' (Rtsa rlung gsang ba'i lde mig)

\section{A Chapter from Pema Lingpa's Compendium of Enlightened Spontaneity} (Rdzogs chen kun bzang dgongs'dus). ${ }^{42}$

\section{Homage to Absolute Goodness, Samantabhadra (kun tu bzang po)!}

I, the Powerful Skull-Garlanded Lotus (Rdo rje thod phreng rtsal) ${ }^{43}$ have composed this 'Secret Key' to elucidate the [nature of the] Inner Winds (rlung, Skt: prāna) in order to help practitioners open their subtle channels, balance the three humors of wind, bile and phlegm, and ensure physical [and mental] health.

In an isolated place free from disturbances, abide in the non-conceptual space of thod rgal [leaping over] and generate boundless love and compassion for all beings. ${ }^{44}$

${ }^{42}$ KZGD, vol. 2, pp. 453-60.

43 A title of Padmasambhava.

${ }_{44}$ The yogic practices of channels and winds (rtsa rlung) which follow are in preparation for the Dzogchen practices of ka dag khregs chod and lhun grub thod rgal, 'cutting through to primordial purity' and 'spontaneous direct approach', the latter of which relies upon subtle channels connecting the heart and eyes. Although khregs chod commonly precedes the practice of thod rgal, early Nyingma expositions of Nyingtik, or 'Heart Essence', often teach thog rgal first. As with all practices of Vajrayāna Buddhism they are framed by the altruistic Mahãyaña intent to achieve enlightenment on behalf of all beings. 


\section{THE YOGIC MOVEMENTS [FOR CLEARING HINDRANCES] ${ }^{45}$}

First, expel the stale winds three times [from the two side channels]. ${ }^{46}$ Then rub the palms of your hands together and massage the left and right sides of your body.

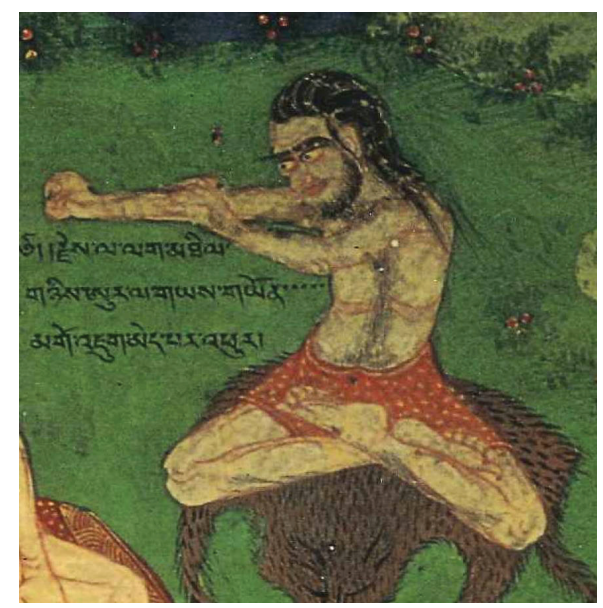

Second, turn your feet outward and alternate turning them to the left and right.

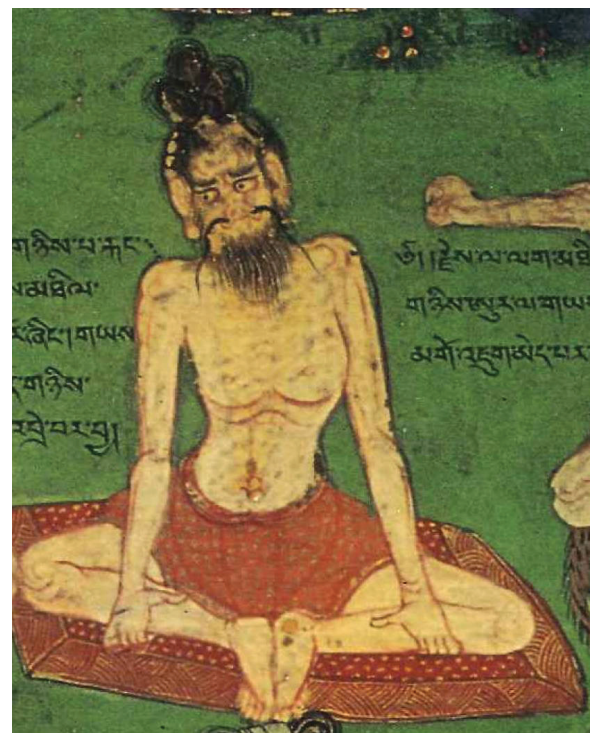

45 To illustrate Pema Lingpa's text I have inserted the relevant image from the paintings on the northern wall of the Lukhang temple. The captions visible in the illustrations are taken directly from Pema Lingpa's text. For a detailed description of an elaborate system of 'khrul 'khor attributed to Vairocana, a contemporary of Padmasambhava, see Norbu 2008. See also Wangyal 2011 and publications by Chaoul-Reich for further explication of 'khrul 'khor within the Tibetan Bon tradition.

46 Similar to methods of nädi shodana in hathayoga, the stagnant winds are cleared through forceful exhalation through alternate nostrils while the other nostril is held closed with the thumb or ring finger. 
Third, apply [sesame] oil [to the body] and shake.

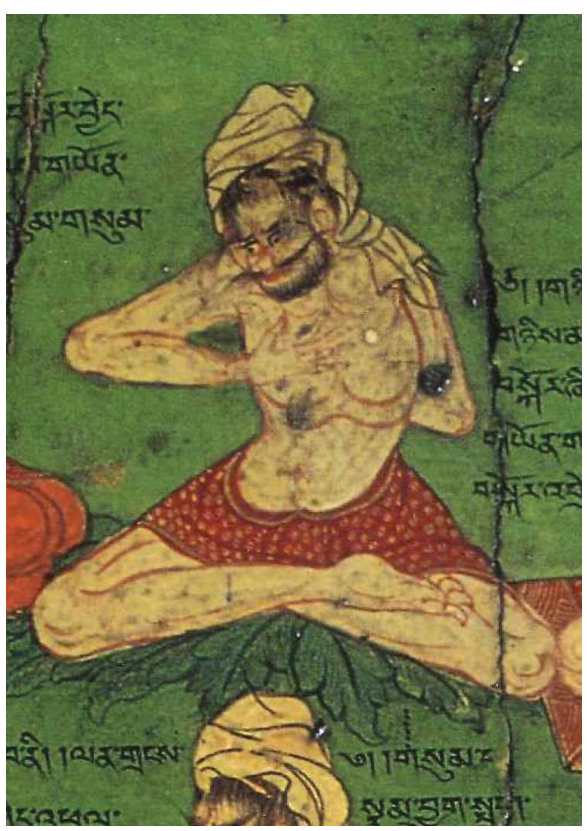

Fourth, churn the abdomen three times to the left and three times to the right. ${ }^{47}$

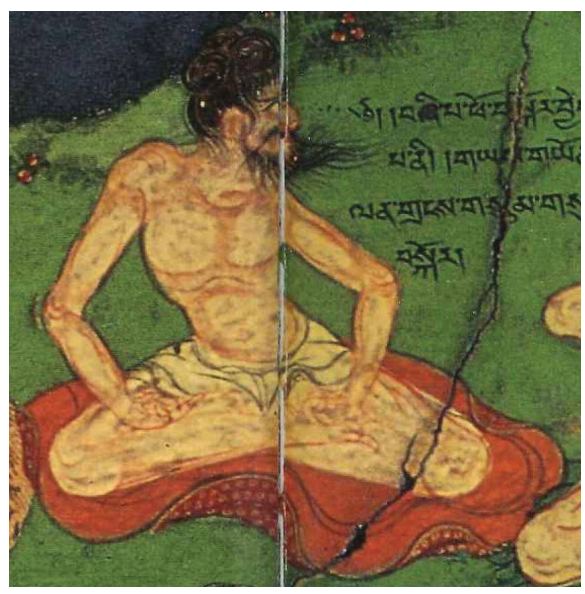

${ }^{47}$ Unlike uddiyana bandha and nauli in hathayoga, the abdomen is not pulled in directly to the spine. 
Fifth, as if pushing a vajra, hold your breath [in the lower abdomen] and firmly press out your two arms.

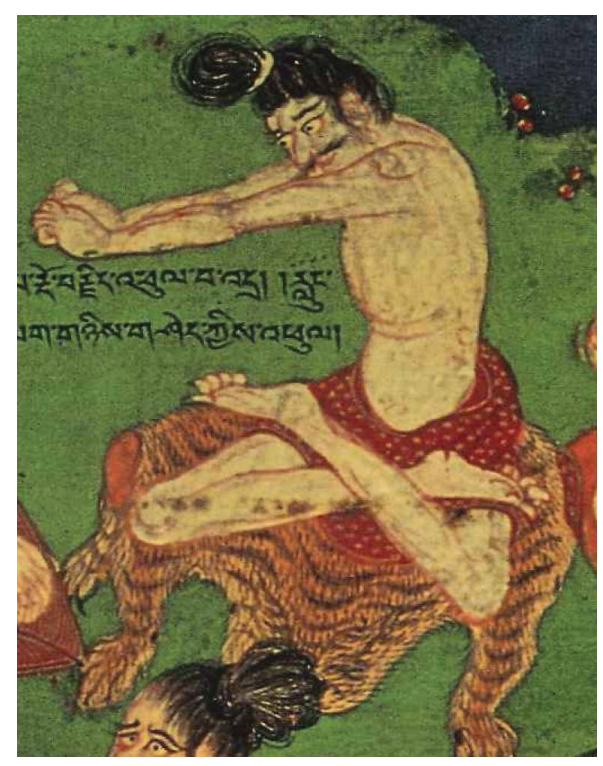

Sixth, like throwing a rock, fling your left and right arms outwards three times. ${ }^{48}$

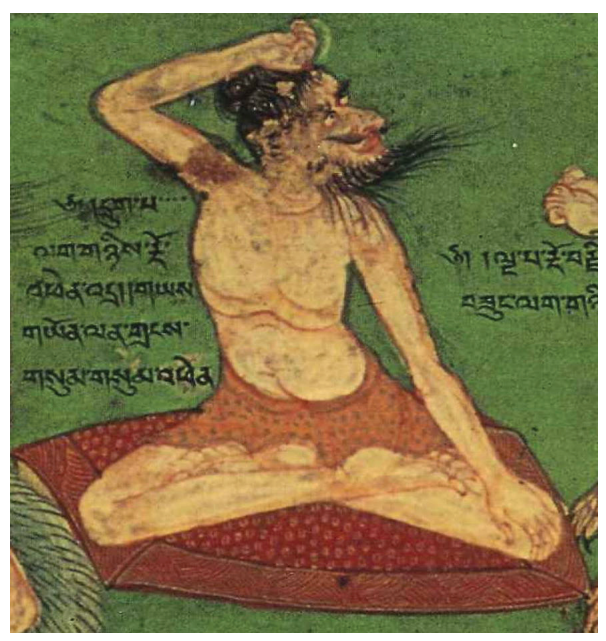

${ }^{48}$ This movement has the reputed benefit of opening the lung and heart meridians associated with traditional Chinese medicine. 
Seventh, rotate the wrists inwards and outwards three times each.

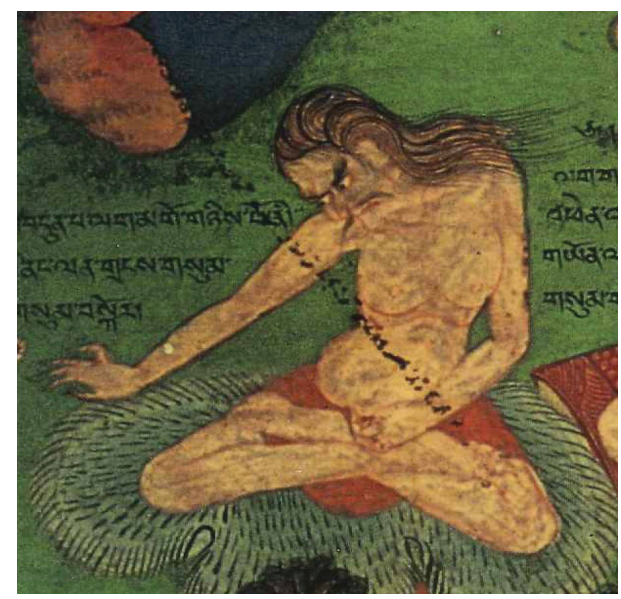

Eighth, while holding the breath [in the lower abdomen], rotate the entire body and the heart-centre three times to the left and right and exclaim HA HA.

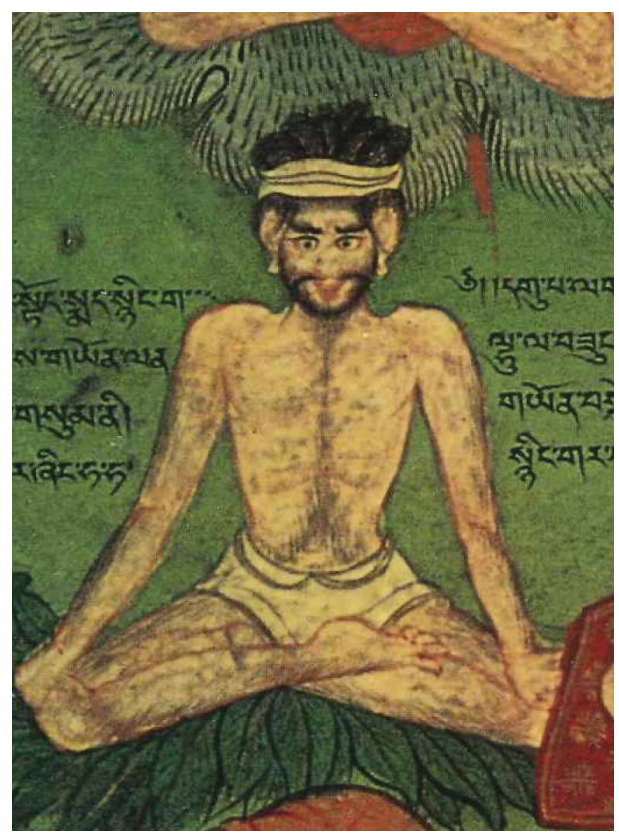


Ninth, with your two hands [crossed in front and] holding your upper arms rotate to the left and right and then strike the heart-centre.

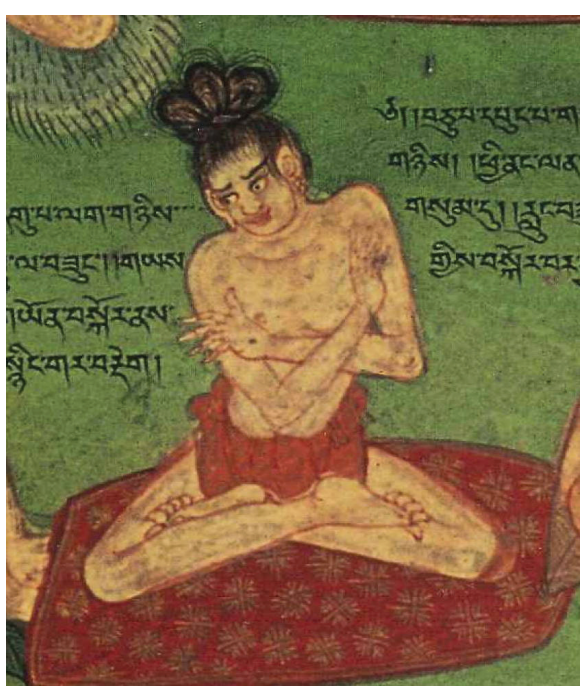

Tenth, while holding the breath [in the lower abdomen], rotate your left and right shoulders in and out three times each [with the arms straight and the fists pressing against the thighs].

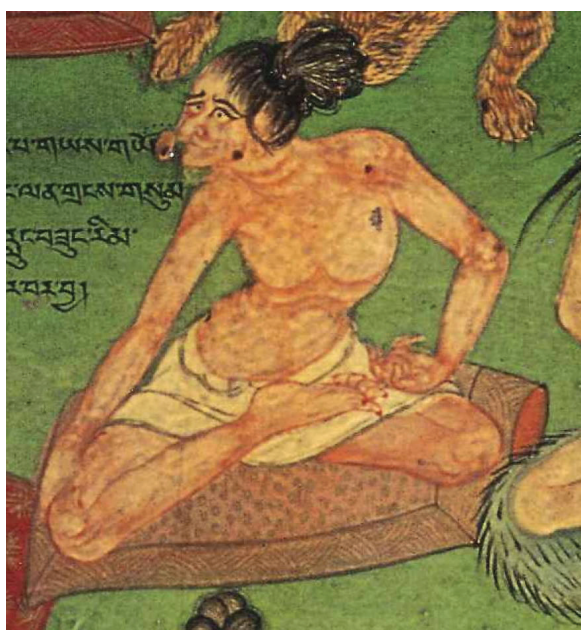


Eleventh, strongly strike your fists nine times against your navel.

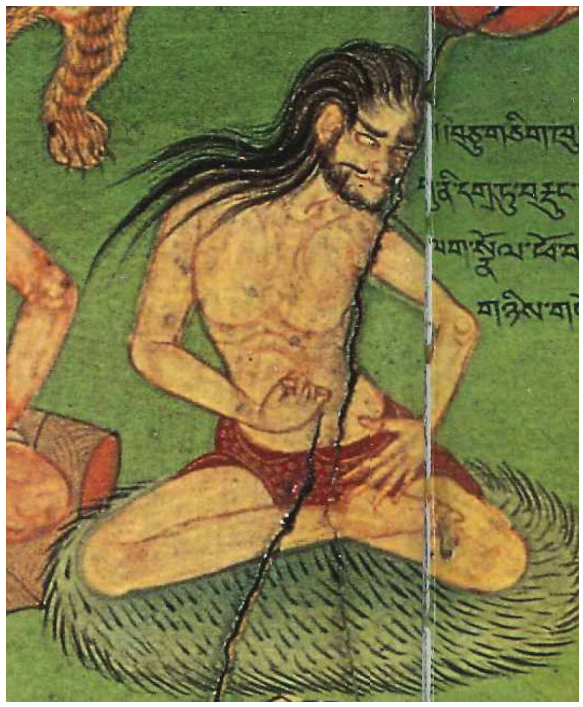

Twelfth, join your palms at the heart-centre and alternate striking your elbows against the sides of the ribs and then bang both [elbows against the body] simultaneously.

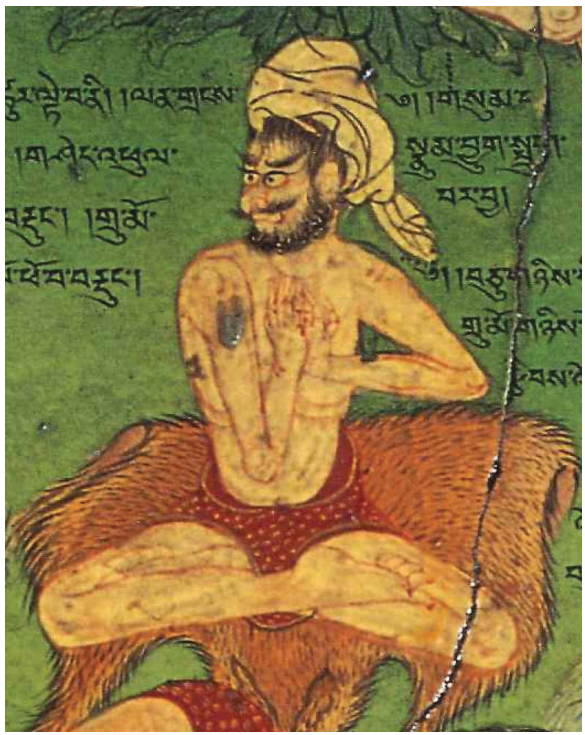


Thirteenth, interlacing your fingers, push back against the back of the neck and rotate [the head] three times to the left and three times to the right.

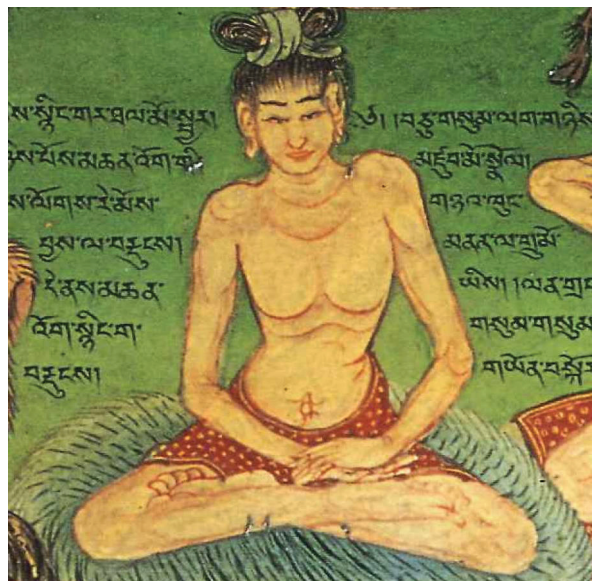

Fourteenth, like drawing a bow, pull three times to the left and three times to the right and, while crossing the arms, strike the point of the shoulder. ${ }^{49}$

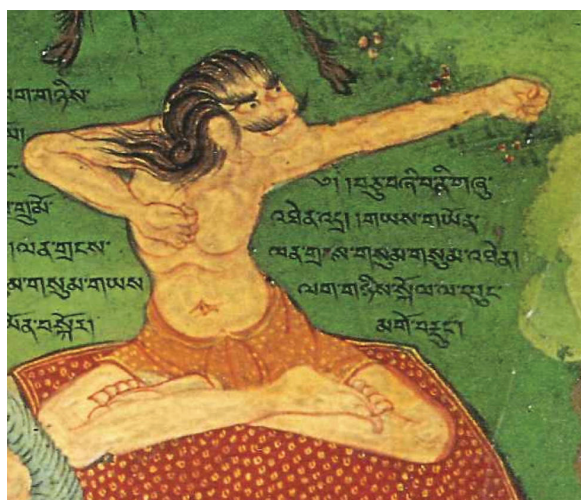

Fifteenth, rotate the head and eyes three times to the right and three times to the left. Then stretch the head nine times to the back and front, and nine times from side to side. Then shaking [the head] nine times, expel all stagnant air.

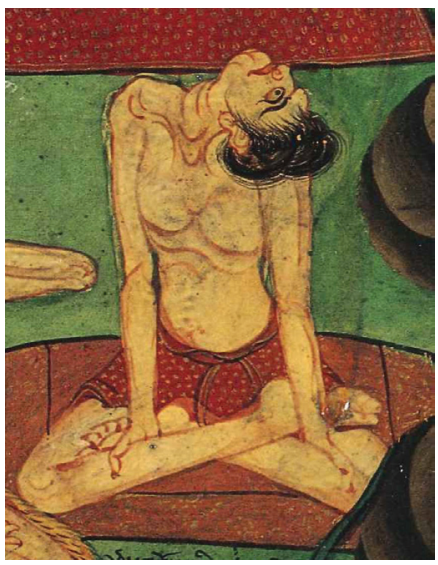

49 This movement is said to unblock and open the heart-centre, freeing it from stagnant 'wind' (rlung) and unproductive mental states. 
Sixteenth, the 'Lions Frolic': Seal the eyes with the two index fingers, block the ears with the two thumbs, block the nostrils with the middle fingers and, with the small and ring fingers, seal the lips. ${ }^{50}$ Rotate the head three times to the left and three times to the right. Then shake [the upper body] three times.

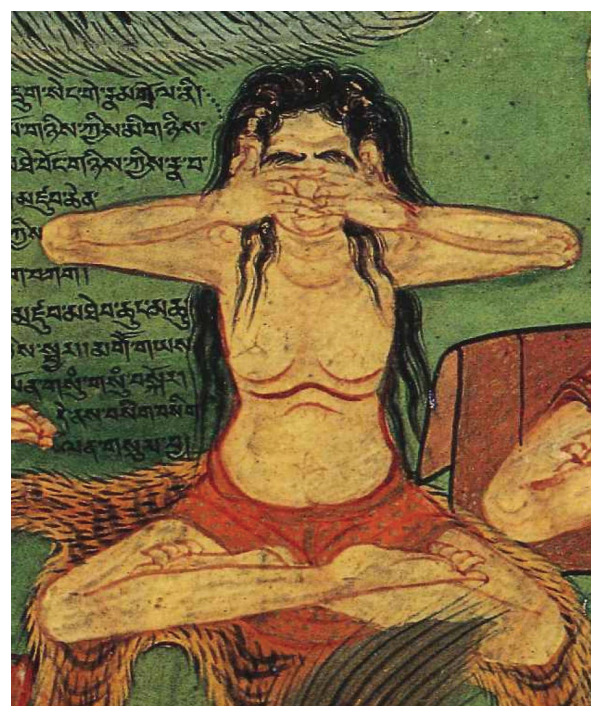

Seventeenth, while standing up, shake the legs to the back and front and from left to right. Turn the arms to the left and right and shake them to the front.

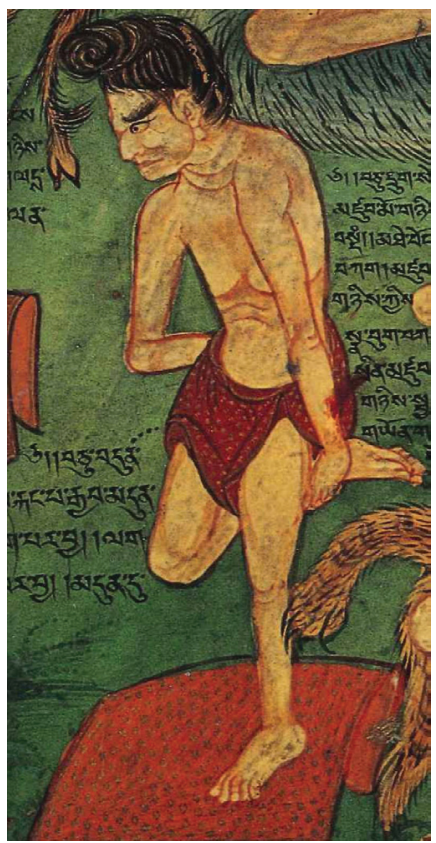

50 This method of closing the doors to the senses is described in Patañjali's Yoga Sutras as pratyahara (so sor sdud pa), the inward withdrawal of the senses towards progressively deeper states of unitary awareness. 
Eighteenth, bend forward and touch the hands to the ground. Standing up, repeat nine times.

Nineteenth, while standing up strike the heels [on the ground] then, rising up, jump. Then alternate shaking the arms and legs.
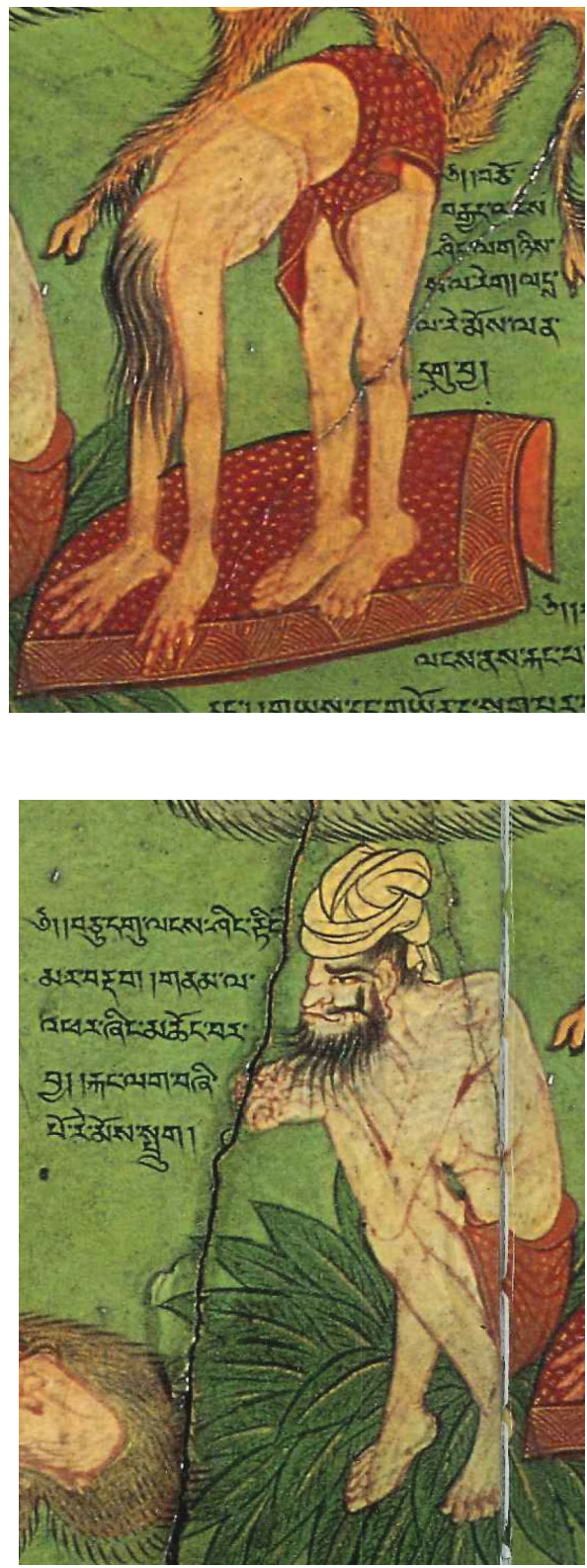
Twentieth, sit in [full lotus] vajra posture and lift up the body [with the hands pressing against the ground], then drop the body against the floor. Do this three times, shaking the body into wakefulness.

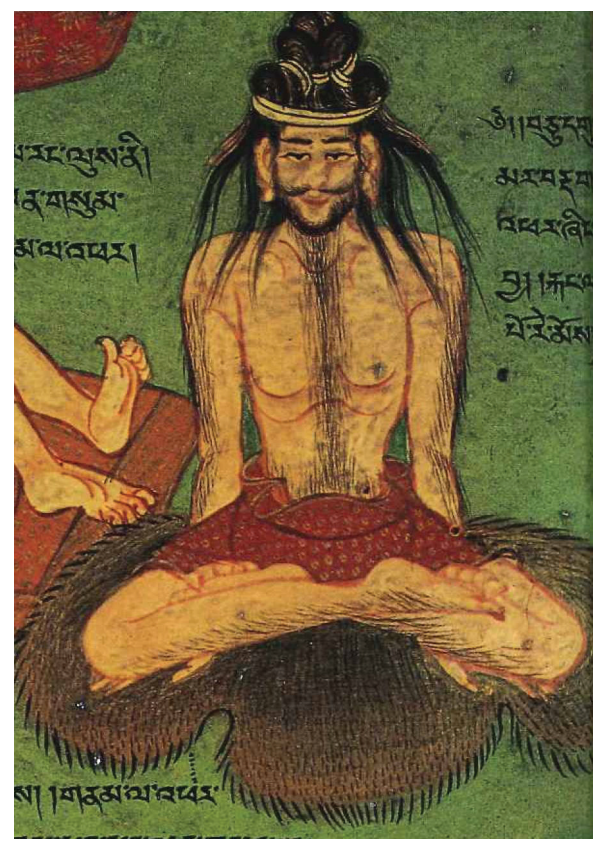

Twenty-first, while lying back, hold the breath [in the lower abdomen] and lift your body up three times.

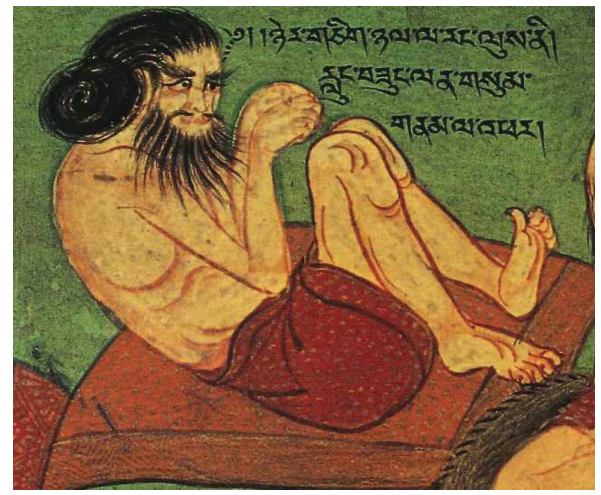


Twenty-second, bend forward and touch the forehead to the ground. Then rolling back, touch the toes to the ground. Shake the body and utter a strong HA three times.

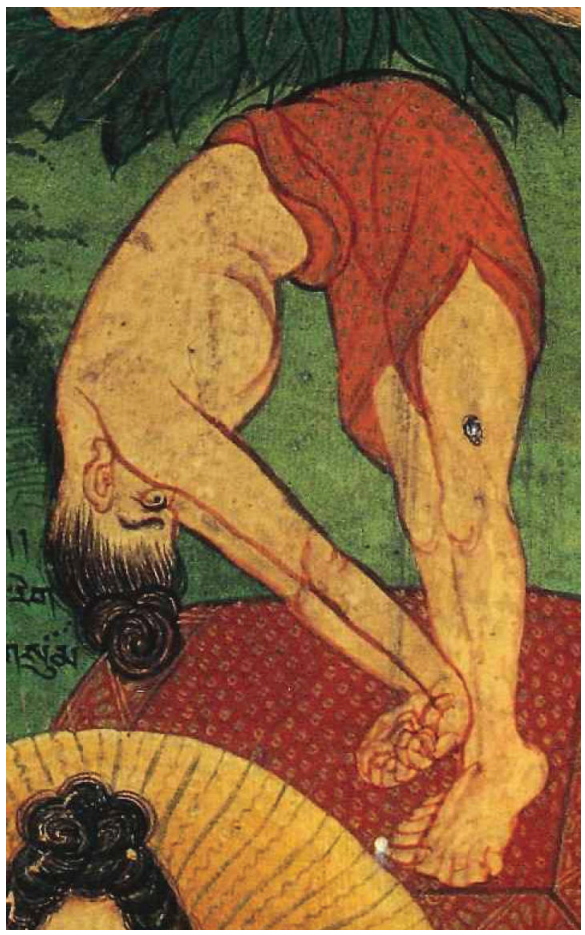

Twenty-third, sit comfortably in the seven-point posture of Vairocana. ${ }^{51}$

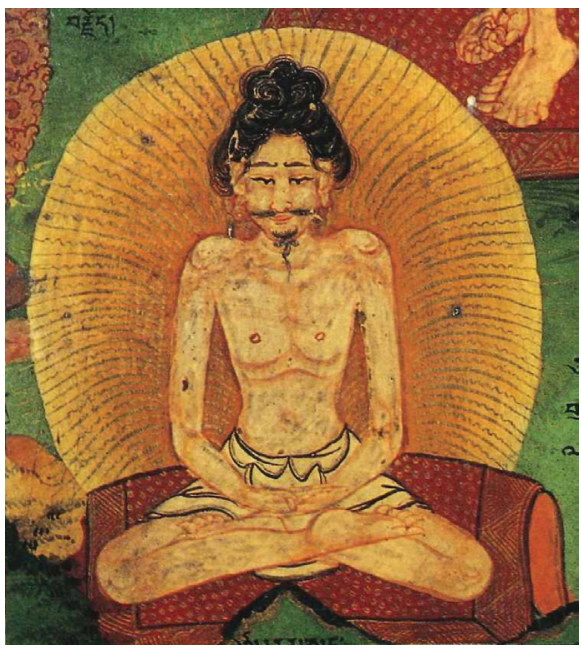

51 See note 32 . 
I, Pema [Padmasambhava], wrote down these 23 secret yogic movements. I pray to my heart son [Pema Lingpa] that they will be of benefit for all beings.

This completes the first section, the stage of 'khrul 'khor [the yogic movements].

Samaya. Sealed! Sealed! Sealed!

\section{THE CHANNELS OF THE HUMAN BODY 52}

In the crown chakra of great bliss

There are three hundred and sixty channel petals;

In the throat chakra of gathering taste

There are sixteen channel petals;

In the heart-centre, the dharma chakra

There are eight channel petals;

In the navel chakra of emanation;

There are sixty-four channel petals;

In the secret centre, the chakra of preserving bliss $5^{33}$

There are twenty-eight channel petals.

The entire body contains twenty-one thousand channel petals.

The three principal channels are:

The uma, roma, and kyangma. ${ }^{54}$

52 The presentation of the subtle energy channels (rtsa, Skt: nädi) in Tibetan Buddhism derives from Indian sources and varies in its enumeration of the number and location of specific channels and energy plexuses ('khor lo, Skt: cakra). The Tantras and Tibetan medical systems generally describe 72,000 such channels within the human body that allow for the flow of awareness throughout the physical organism. The hollow, tubular ducts are described as symbolising the unlimited space through which consciousness can express itself, with the thig le, or psychophysical essences, representing the base for all appearance and manifestation. Pema Lingpa's overview of the subtle body focuses on three principal energy channels that parallel the spine and which, along with five associated energy plexuses ( $c a k r a)$, form the basis for the completion stage practices of Anu Yoga (rjes su rnal 'byor).

53 This refers to the root chakra in the genital region that serves as a reservoir of bliss so long as the relative thig le, or sexual fluids, are retained and not lost through ejaculation, especially within the context of dual-cultivation with a consort (las kyi phyag rgya, Skt: karmamudrā).

${ }_{54}$ The three fundamental channels rtsa dbu ma, ro ma, and rkyang ma differ in fundamental ways from the susumnā, idā, and pingala nädi described in hathayoga. In the Dzogchen view of embryology, the navel chakra develops first, followed by the crown chakra as a result of a connecting 'life-channel' ( $\operatorname{srog} r t s a$ ) that further differentiates into the spinal cord and spine, yet remains as the unifying energy of the rtsa dbu ma (Skt: avadhüti) central meridian at the core of tantric yoga. Four finger-widths below the navel, the dbuma intersects with two ascending lateral channels called ro ma and rkyang ma. The ro ma is visualised as white in colour and as corresponding to lunar energy. It is said to lie on the right side of the body in men and on the left side in women. $R o$, in Tibetan, means 'flavour', and the principal function of the ro $m a$ is to provide 
Their inner space is erect like pillars.

Their upper ends appear like the horns of the bamen ['wild ox'];

Their lower ends are curved like the Tibetan letter cha.

Uma, the channel of the wisdom flow,

Has three different names: ${ }^{55}$

Outwardly it is known as Uma [the 'central'], inwardly as Kundarma [the 'allencompassing'],

And secretly as Shel Bugchen, [the 'great crystalline tube']. ${ }^{56}$

It is empty and transparent and free of blood and fluids. Along its length are four principal channel wheels [cakra] through which the Awareness Wisdom (rig pa'i ye she $)^{57}$ flows unimpeded. Primordial Awareness (rig pa) is supported, in turn, by a luminous energetic sphere [located at the heart cakra]. The twenty-one thousand channel petals [of the subtle body] connect to twentyone thousand internal winds that differentiate the pure and impure essences (thig le) of the body.

This completes the section on the subtle channels ( $r t s a)$ of the physical body.

Samaya. Sealed! Sealed! Sealed!

the sensation of pleasure. The ro ma is thus further correlated with the tantric principle of thabs lam, or method. The rkyang ma is connected with the principle of 'grol lam, or liberation and is visualised as red and as corresponding to solar energy. It lies on the left side of the body in men and on the right side in women. Rkyang means 'sole', and unlike the ro ma, the rkyang ma is not connected with any secondary channels. Control of the energies that flow through the rkyang ma is considered fundamental for developing insight into emptiness as the energetic basis for all manifestation. The goal of all practices connected to the channels and winds (rtsa rlung) can be generalised as the unification of the energies of the body's two lateral channels into the wisdom flow of the central meridian ( $r t s a d b u m a$ ) that runs from the base of the spine to the crown of the head, an energetic current possibly related in human anatomy to the prenatal notochord.

55 The three principal channels further correlate with Dzogchen's presentation of the triune reality of the ground of being (kun gzhi). The Essence or Pure Potentiality (ngo stong pa) relates to the avadhüti itself, the Luminous Nature (rang bzhin gsal ba) to the ro ma, and the unceasing Energy of Manifestation (thugs rje kun khyab) to the rkyang ma.

56 This microscopic and translucent channel is described in Dzogchen as originating in the innermost centre of the heart chakra and rising up through the central channel into the brain where it bifurcates and arcs forward to terminate at the centre of the pupils of both eyes. In distinction to the channels that circulate präna, or vital energy, the crystalline kati channel is described in oral tradition as a 'light channel' that connects the Clear Light wisdom located in the heart chakra with the Clear Light awareness 'seated' in the brain. As with all practices of Dzogchen, it remains 'secret' until manifested through direct experience.

57 The Tibetan word rig pa generally means 'intelligence' or 'awareness'. In Dzogchen, it further refers to 'the innermost nature of the mind' as distinct from ordinary mental processes. The word ye shes generally translates as 'primordial wisdom' and is an intrinsic feature of enlightened consciousness. 


\section{IGNITING BLISS AND HEAT TO ENHANCE REALISATION ${ }^{58}$}

Expel the stale airs three times [from each nostril] and inhale in an instant the essence of the wisdom prana from the tip of the nose and swallow the saliva. Pull up the lower winds [by gently contracting the pelvic floor] and [while pressing down with the upper winds] hold the energy at the navel centre [by applying the 'Vase Breath' (bum can, Skt: kumbhaka)]. Then gradually perform the 'khrul 'khor [the 23 yogic movements].

[Again] expel the stale winds three times [from the side channels]. Then gently unite the lower and upper winds [at a point four finger widths below the navel] by applying 'jam rlung [exhaling and inhaling softly and completely with a gentle breath retention]. Next, visualise the central channel ( $r t s a d b u$ ma) as ascending from the secret centre [genitals] to the crown [of the head], empty and unimpeded, the size of a bamboo arrow, bluish white and free of blood, lymph, or any fluids. ${ }^{59}$

At the navel chakra, within the central channel, is a red four-petalled lotus. In its centre is the syllable Yam and, on top of it, a red Ram. ${ }^{60}$ Wind stirs from the Yam and strikes the Ram, igniting a fire that rises [within the central channel]. When the flame touches the white [inverted] Ham at the crown chakra, it causes the red and white essences (thig le) to descend. When they reach the Ram at the navel chakra the inner fire blazes and incinerates all habitual [and limiting] tendencies [of the mind]. While meditating on the

58 This section describes the technique of gtum mo, literally 'fierce female energy', which corresponds with the Indian system of candālī or kundalinī yoga. In the context of Vajrayāna Buddhism the incandescent bliss that rises through the practice is not an end in itself but 'expedient means' (thabs lam, Skt: upäya) for recognising the true nature of the mind and thus achieving liberation from conditioned states, including attachment to bliss itself. All Dzogchen methods can be divided into either bogs 'don or bgegs sel, practices that either enhance the realisation of non-dual wakefulness (such as gtum mo) or those that dispel hindrances (such as 'khrul'khor).

59 See note 63 for discussion of the role of the central channel in tantra and Dzogchen. For the practice of gtum mo there are two main bodily positions. In the first, the practitioner sits cross-legged with the arms held along the sides of the body with the hands turned upward and, with thumbs connected to the roots of the ring fingers, pressed against the insides of the thighs as 'vajra fists'. In the second position, one sits with the legs raised in front with arms crossed and the elbows resting on the tops of the knees to simulate a 'stove', often supported by a meditation belt.

${ }^{60}$ Yam and Ram are seed-syllables (yi ge) signifying air and fire. Ham, visualised in Pema Lingpa's presentation of gtum mo as located at the crown of the head, represents water, or the dimension of fluidity. In other contexts, this practice is also performed by visualising a short blazing 'Ah' four finger-widths' beneath the navel that, in turn, causes the 'white element' at the crown of the head to melt and drip down through the central channel. 
expanding bliss, imagine that you are receiving the third empowerment ${ }^{61}$ that [activates the channels and winds and] awakens the innate heat and wisdom [of the umbilical centre].

This completes the third section of meditating on Gnostic Fire (gtum mo) in the evening. ${ }^{62}$

Samaya. Sealed! Sealed! Sealed!

\section{ENTERING CONSCIOUSNESS INTO THE VASE AT NIGHT ${ }^{63}$}

[For the practice of sleep] lie on your right side and meditate that the central channel $(d b u m a)$ is the size of an arrow and empty and transparent and free of blood and fluids. Primordial Awareness (rig pa) abides as a white Hum ${ }^{64}$ at the navel chakra, in the centre of a four-petalled lotus. The Hum is unmoving, clear, and brilliant. Contemplate that all the coarse and subtle thoughts that ride on the vehicle of the breath dissolve into the upward-facing Hum. When thoughts arise, concentrate on the Hum at the navel chakra.

Following this, at the point of sleep, imagine your Primordial Awareness as a radiant white Hum blossoming in your heart chakra at the centre of a fourpetalled lotus. Meditate that all thoughts [and sensations] dissolve into this luminous Hum. Join the lower and upper winds at your heart chakra. The Hum shines within the heart like a lamp inside a vase. Meditate on clarity and emptiness free of grasping and your sleep will naturally arise as unobstructed

${ }^{61}$ Vajrayāna practice is normally connected to receiving four successive tantric empowerments (dbang bzhi) that prepare the mind and body for the experiences that arise through the practices of the Inner Tantras. The third empowerment of 'knowledge-wisdom' (shes rab ye shes kyi dbang) authorises the practitioner to meditate on the union of bliss and emptiness aroused by the Anu Yoga practices of gtum mo, rtsa rlung, and karmamudrā.

62 When gtum mo is combined with other Anu Yoga practices, it is conventionally performed in the evening; otherwise it may be practised at any time of day or night.

${ }^{63}$ 'Vase' refers, in this context, to the containing of the senses as one falls asleep. The vase into which the sensory functions are withdrawn can refer to either the heart chakra or the navel chakra.

64 The seed-syllable 'Hum' refers in Vajrayāna Buddhism to the innate wisdom mind while, in Dzogchen, the seed-syllable 'Ah' represents the mind's primordial nature (Logos). While the syllable 'Hum' is illustrated on the western mural in the context of the preliminary Dzogchen practices, 'Ah' is pictured far more frequently and often substitutes for instances in which Pema Lingpa's text specifies the visualisation of a 'Hum'. In any case, the practice described here, 'Retaining Wakefulness in the Vase', is often done while visualising an 'Ah' at the centre of the heart which lights up the interior of the body and radiates beyond it, leading to 'capturing Luminosity during deep sleep'. 
Luminosity. Meditate in this way again and again and the movement of outer and inner thoughts will dissolve into [all-pervasive] Clear Light. This completes the fourth section of entering the objects of consciousness into the vase.

Samaya. Sealed! Sealed! Sealed!

\section{LEAVING AWARENESS IN ITS NATURAL STATE IN THE EARLY MORNING}

At the moment of waking, sit in the rssi posture ${ }^{65}$ and expel the stale winds three times [from both nostrils]. Then, release the two winds [that were joined] at your heart-centre and [while shouting Ha into the sky] project the Hum through the crown of your head to a bow's length above and in front. Focus your Awareness and internal energy (rlung, Skt: präna) on the Hum [in the sky above you] while holding a gentle 'vase breath'. ${ }^{66}$ Meditate undistractedly in a state of naturalness, giving rise to non-conceptual wisdom. Allow the Hum to naturally dissolve [into infinite space] and remain free of all conceptual activity.

When the sun shines focus [your attention] on [the naturally arising visions of] thod rgal. ${ }^{67}$

Spend your days and nights in contemplation of ultimate reality.

An instruction of this type cannot be found in Tibet or India.

${ }^{65}$ One of three positions emphasised for the practice of thod rgal, the rssi posture consists of sitting with an erect spine with the legs pulled up in front and the arms either around or resting on top of the knees. This practice is also commonly done while crouched in the 'lion's posture'. [See figure 13]

${ }^{66}$ In the practice of thod rgal, breathing occurs almost imperceptibly through the mouth without any manipulation of the prāna. The out breath is naturally longer with a gentle holding of the empty breath before inhaling. In Anu Yoga, prāna is controlled so as to control the mind. In Ati Yoga, the mind is controlled so as to bring prāna naturally into balance.

${ }_{67}$ The visions of thod rgal can be compared with so-called blue field entoptic phenomena identified in 1924 by the German ophthalmologist Richard Scheerer and described as the appearance of bright dots flowing along wave-like lines in the visual field when looking into bright blue light, such as the sky. Ophthalmologically, the dots appear as a result of leukocytes, or white blood cells, flowing through the macular, retinal capillaries of the eyes in synchrony with the cardiac cycle between the beginning of one heartbeat and the onset of the next. In a convergence of science and traditional accounts, the luminous orbs that appear before one's eyes are manifestations of the cellular structure of one's own blood, or heart essence (nying thig). The blue field entoptic phenomena are distinct from other entoptic phenomena such as 'floaters' (muscae volitantes) which result from debris floating on the eye's vitreous humor. In the context of thod rgal, subjective entoptic phenomena and associated hypnogogic imagery serve as affective entry points into liberative non-dual states of consciousness. 
This sacred heart blood of me, Pema [Padmasambhava], may it meet with my destined heart son [Pema Lingpa].

\title{
Samaya, Sealed! Sealed! Sealed!
}

\author{
The light rays of Orgyen Pema's [Padmasambhava's] compassion \\ Opened the lotus heart of me, Pema [Lingpa and revealed] \\ The supreme path to accomplish the stainless Buddha [Nature]. \\ For the benefit of suitable practitioners \\ The light rays of the white conch scrolls shone forth, \\ And were written down from the yellow parchment [shog gser]. \\ May the teachings spread throughout the world.
}

\section{References}

Aris, M. 1979, Bhutan: The Early History of a Himalayan Kingdom, Warminster, England: Aris $\&$ Phillips.

- 1980, 'Analysis of the Biographies of Padmasambhava According to Tibetan Tradition', Tibetan Studies in Honour of Hugh Richardson, edited by M. Aris and Aung San Suu Kyi, Warminster: Aris \& Phillips.

- 1988, Hidden Treasures and Secret Lives: A Study of Pemalingpa (1450-1521) and the Sixth Dalai Lama (1683-1706), Delhi: Motilal Banarsidass.

Baker, I. 1997, The Tibetan Art of Healing, London: Thames \& Hudson.

—. and T. Laird 2011 [2000], The Dalai Lama's Secret Temple: Tantric Wall Paintings from Tibet, London: Thames \& Hudson.

Birch, J. 2011, 'The Meaning of Hața in Early Hathayoga', Journal of American Oriental Studies 131.4.

Chagme, K. (trans. B. Alan Wallace) 2000, Naked Awareness: Practical Instructions on the Union of Mahamudra and Dzogchen, Ithaca NY: Snow Lion Publications.

Chaoul-Reich, A. 2006, 'Magical movements ('phrul 'khor): Ancient Yogic Practices in the Bon Religion and Contemporary Medical Perspectives', Houston: Rice University Dissertation.

Dargyay, E. 1977, The Rise of Esoteric Buddhism in Tibet, Delhi: Motilal Banarsidass.

Dorji, C. T. 1995, A Political and Religious History of Bhutan, Delhi: Prominent Publishers.

Douglas, K., and G. Bays (trans.) 1978, The Life and Liberation of Padmasambhava, 2 vols, Berkeley: Dharma Publishing.

Dowman, K. (trans.) 1984, Sky Dancer, London: Routledge and Kegan Paul.

Dudjom Rinpoche, J. Y. D. 1991, The Nyingma School of Tibetan Buddhism: Its Fundamentals and History, trans. Gyurme Dorje and M. Kapstein, 2 vols, Boston: Wisdom Publications.

Evans-Wentz, W. Y. (ed.) 1954, The Tibetan Book of the Great Liberation, London: Oxford University Press.

Gangteng, Literary Committee (2008), The Rosary of Jewels: Biographies of the Successive Throne Holders of Gangteng, Bhutan: Gangteng Monastery.

Guenther, H. 1987, The Symbolic Recreation of the World According to the Tibetan Buddhist Tradition of Tantric Visualisation Otherwise Known as The Developing Phase, LOTSAWA.

Gyatso, J. 1992, 'Genre, Authorship, and Transmission in Visionary Buddhism: The Literary Traditions of Thang-stong rGyal-po', Tibetan Buddhism: Reason and Revelation, edited by R. Davidson and S. Goodman, Albany: State University of New York Press. 
1996, 'Drawn from the Tibetan Treasury: The gTer ma Literature', Tibetan Literature: Studies in Genre, edited by J. Cabezón and R. Jackson, Ithaca, NY: Snow Lion Publications. —. 1998, Apparitions of the Self: The Secret Autobiographies of a Tibetan Visionary,. Princeton: Princeton University Press.

- 2012, 'Looking for Gender in the Medical Paintings of Desi Sangye Gyatso, Regent of the Tibetan Buddhist State', Asian Medicine: Tradition and Modernity 6: 217-92.

Gyurme Dorje, T. L. 1994, Total Illumination of the Essence: The Teaching Manual for The Union of Samantabhadra's Intentions, Boulder, CO: Yeshe Korlo Publications.

Harding, S. 2003, The Life and Revelations of Pema Lingpa, Ithaca, NY: Snow Lion Publications.

Kapstein, M. 1989, 'The Purificatory Gem and Its Cleansing: A Late Tibetan Polemical Discussion of Apocryphal Texts', History of Religions 28(3): 217-44.

- 2000, The Tibetan Assimilation of Buddhism: Conversion, Contestation, and Memory, Oxford: Oxford University Press.

- 2006, The Tibetans, Oxford: Blackwell Publishing.

Kongtrul, J. 2005, The Treasury of Knowledge, Book Six, Part Four: Systems of Buddhist Tantra, translated by E. Guarisco and I. McLeod, Ithaca, NY: Snow Lion Publications.

Kvaerne, Per. 1990, 'Review of Hidden Treasures and Secret Lives', Acta Orientalia 51: 302-6.

Lipman, K. 1987, 'The Dynamic Yoga of Tibet: Combining Asanas, Breathing Exercises, and Flowing Movements, Yantra Yoga Aims to Return us to our "Natural State"', cited in Yoga Journal, May 1987, no. 74, Active Interest Media. ISSN 0191-0965.

Luczantis, C. 2011, 'Locating Great Perfection: The Murals of the Lhasa Lukhang', Orientations 42(2): 102-11.

Mayer, R. 1992, 'Review of Hidden Treasures and Secret Lives', Religion 22(2): 187.

Mullin, G. 2006, The Practice of the Six Yogas of Naropa: Tsongkhapa's Commentary, Ithaca, NY: Snow Lion Publications.

Namdak, T. and R. Dixey 2002, Heart Drops of Dharmakaya, Boston: Wisdom Publications.

—. and J. Myrdhin Reynolds 2006, Bonpo Dzogchen Teachings, Boston: Wisdom Publications.

Norbu, N. (trans. A. Clemente) 2008, Yantra Yoga: The Tibetan Yoga of Movement, Ithaca, NY: Snow Lion Publications.

Odier, D. 2005, Yoga Spandakarika: The Sacred Texts at the Origin of Tantra, Rochester, VT: Inner Traditions.

Parfionovitch, Y., G. Dorje and F. Meyer (eds) 1992, Tibetan Medical Paintings: Illustrations to the Blue Beryl Treatise of Sangye Gyamtso (1653-1705), 2 vols, London: Serindia Press.

Robinson, J. 1996, 'The Lives of Indian Buddhist Saints: Biography, Hagiography and Myth', Tibetan Literature: Studies in Genre, edited by J. Cabezón and R. Jackson, Ithaca, NY: Snow Lion Publications.

Samuel, G. 1993, Civilized Shamans: Buddhism in Tibetan Societies, Washington, DC: Smithsonian Institution Press.

- 2008, Origins of Yoga and Tantra: Indic Religions to the Thirteenth Century, Cambridge: Cambridge University Press.

Singh, J. 1979, Siva Sutras: The Yoga of Supreme Identity, Delhi: Motilal Benarsidas.

Singleton, M. 2010, Yoga Body: The Origins of Modern Postural Practice, Oxford: Oxford University Press.

- and J. Mallinson (forthcoming), The Roots of Yoga: A Sourcebook of Indic Traditions.

Snellgrove, D. 1987, Indo-Tibetan Buddhism: Indian Buddhists and their Tibetan Successors, Boston: Shambhala Publications.

Thondup, T. 1986, Hidden Teachings of Tibet: An Explanation of the Terma Tradition of Tibetan Buddhism, Boston: Wisdom Publications. 
1990, 'The Terma Tradition of the Nyingmapa School', Tibet Journal 15(4): 149-58.

Thurman, R. 1991, 'Review of Hidden Treasures and Secret Lives', The Journal of Asian Studies 50(2): 375-7.

Tshewang, P. 1995, 'The Biography of Pemalingpa', in Tshewang et al., The Treasure Revealer of Bhutan: Pemalingpa, the Terma Tradition and its Critics, Bibliotheca Himalayica, series III, vol. 8, Kathmandu, Nepal: EMR Publishing House, 23-98.

Tshewang, P., K. Phuntshok Tashi, C. Butters and S. Saetreng 1995, The Treasure Revealer of Bhutan: Pemalingpa, the Terma Tradition and Its Critics, Bibliotheca Himalayica, series III, vol. 8, Kathmandu, Nepal: EMR Publishing House.

Van Schaik, S. J. 2004, Approaching the Great Perfection: Simultaneous and Gradual Approaches to Dzogchen Practice in the Longchen Nyingtig, Boston: Wisdom Publications.

. 2004b, 'The Early Days of the Great Perfection', Journal of the International Association of Buddhist Studies 27(1): 165-206.

Wangyal, T. 2011, Awakening the Sacred Body: Tibetan Yogas of Breath and Movement, London: Hay House, Inc.

Winkler, J. 2002, 'The rDzogs Chen Murals of the Lhasa Klu-Khang', in Blezer H. et al. (eds), Religion and Secular Culture in Tibet: Tibetan Studies II: Proceedings of the Ninth Seminar of the International Association of Tibetan Studies, Leiden 2000. Leiden: Brill, 321-43.

. (forthcoming), 'The Literary Sources of the Klu-Khang Murals'.

Yeshe, L. T. 1998, The Bliss of Inner Fire: Heart Practice of the Six Yogas of Naropa, Boston: Wisdom Publications. 